\title{
Human herpes simplex virus keratitis: the pathogenesis revisited
}

\section{Lies Remeijer, Albert Osterhaus \& Georges Verjans}

To cite this article: Lies Remeijer, Albert Osterhaus \& Georges Verjans (2004) Human herpes simplex virus keratitis: the pathogenesis revisited, Ocular Immunology and Inflammation, 12:4, 255-285, DOI: 10.1080/092739490500363

To link to this article: http://dx.doi.org/10.1080/092739490500363

Published online: 08 Jul 2009.

Submit your article to this journal $\sqsubset$

Џ Article views: 117

Q View related articles $\square$

场

Citing articles: 2 View citing articles $\square$ 
Taylor \&Francis

healthsciences

Ocular Immunology and Inflammation 0927-3948/04/US\$22.00

Ocular Immunology and Inflammation2004, Vol. I2, No.4, pp. 255-285

(C) 2004 Taylor \& Francis Ltd.

DOI: I0.1080/092739490500363

\section{Human herpes simplex virus keratitis: the pathogenesis revisited}

\author{
Lies Remeijer MD, PhD ${ }^{1}$ \\ Albert D.M.E. Osterhaus DVM, PhD² \\ Georges M.G.M. Verjans, PhD ${ }^{2}$
}

\author{
${ }^{1}$ Dr. Lies Remeijer, The Rotterdam Eye Hospital, Cornea and \\ external disease service Schiedamse Vest 180, 3011BH \\ Rotterdam \\ ${ }^{2}$ Dr. Albert D.M.E. Osterhaus and Dr. Georges M.G.M. Verjans, \\ Institute of Virology, Erasmus Medical Centre, Dr. \\ Molenwaterplein 50, 3015 GE Rotterdam, The Netherlands
}

\begin{abstract}
Infections with several members of the human herpesviruses are the cause of significant ocular morbidity. Of the human herpesviruses, HSV-I is the most frequent cause of primary and recurrent eye disease. Despite the availability of effective antiviral treatment, recurrent HSV-I infection continues to be the leading cause of corneal blindness in industrialized nations. This review recapitulates the current insights in the role of the virus and the intra-corneal $\mathrm{T}$ cell response involved in the pathogenesis of human HSV-I-induced keratitis.
\end{abstract}

Key words Herpes simplex virus; Keratitis; Infection; Pathogenesis; Immune response

\section{Human herpesviruses}

MORPhology AND Classification Virions of Herpesviridae family have a characteristic morphology. An icosadeltahedral capsid surrounds an electron opaque core in which double stranded DNA is located. The capsid itself is surrounded by a tegument and a viral envelope. The viral envelope is the outer surface of the virion in which virus-encoded glycoproteins, exhibited as spikes, are embedded (Fig. I).

The overall size of the virions varies from $120-300 \mathrm{~nm}$. The double stranded DNA genome ranges from I20 to 230 kilo base pairs (kb). ${ }^{\mathrm{I}}$ The genome of herpes simplex virus (HSV) or human herpesvirus type I (HHV-I), the prototype of the Alphaherpesvirinae, has a unique
Correspondence and reprint

requests to:

Dr. L. Remeijer

The Rotterdam Eye Hospital

Cornea and External Disease Service

Schiedamse Vest I80

30 I IBH Rotterdam

Tel: +3 I-(o) I0-40I 7748

Fax:+3 I-(o) I0-4I I I 747

E-mail: schoerem@bart.nl 

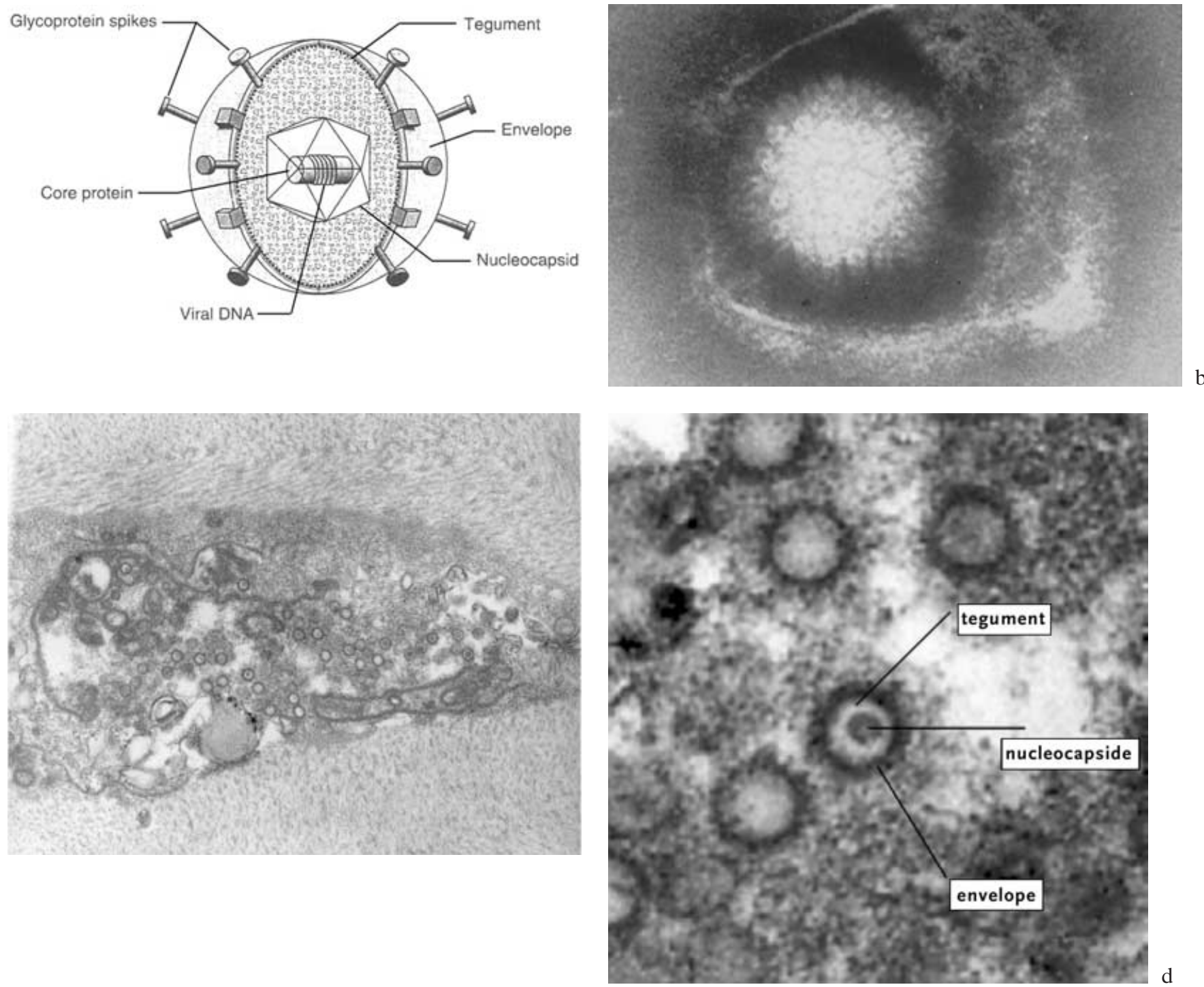

Fig. I. The morphology of herpesviruses.

a. schematic representation of the herpesvirion. Viral DNA is wrapped around a protein core that lies within a icosadeltahedral capsid. Together these form the nucleocapsid. The tegument, an amorphous protein structure, lies between the outer phospholipoprotein membrane and the nucleocapsid. (reprinted with permission from Pavan-Langston, Dunkel E. Varicella Zoster virus diseases: Anterior segment of the eye. In: Pepose JS, Holland GN, Wilhelmus KR, editors. Ocular infection and immunity. St Louis: Mosby-Year Book; 1996. p 934).

b. Electron Micrograph of the capsid of HSV.

c. EM of the nucleus of a human corneal keratocyte with multiple herpes simplex virions.

d. detail of EM c. matching the schematic representation of the virion in a.

organization (Fig. 2). It consists of long double stranded linear molecules with several repeated and inverted sequences. The DNA has two stretches of unique sequences, one long (unique long sequence, $\mathrm{U}_{\mathrm{L}}$ ) and one that is much shorter (unique short sequence, $U_{S}$ ) ${ }^{2,3}$ Each of these long sequences is bracketed by shorter identical DNA repeats. The viral DNA contains terminal and internal reiterated sequences. Because of the variability in the number of these reiterations, the size of individual genomes may vary by more than Io kb. ${ }^{\mathrm{I}}$ The genome of her- 


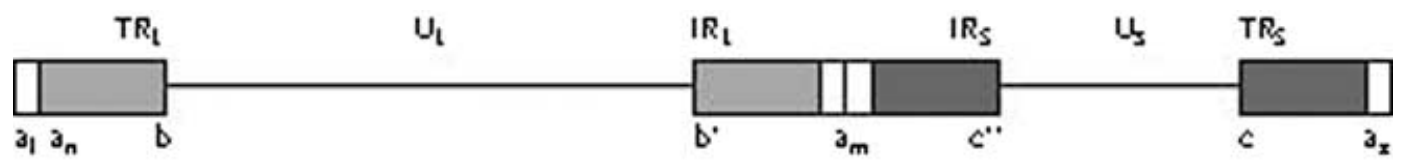

pesviruses encodes about 80 proteins. These proteins have regulatory functions, (e.g. DNA polymerase), or are structural proteins, (e.g. glycoproteins). ${ }^{3}$ The glycoproteins mediate attachment of the virus to cells, the capsid acts as a vector for the viral DNA, ${ }^{4}$ and several tegument proteins are involved in the initiation of viral replication. ${ }^{3}$ Both glycoproteins and structural proteins have been shown to play a role in the adaptive host immune responses. ${ }^{4,5}$

The family Herpesviridae comprises a group of ancient large DNA viruses that are widespread in the animal world, having mammals, fish, birds and reptiles as their host species. They are classified into three subfamilies $\alpha, \beta$ and $\gamma$, initially primarily on basis of tissue tropism and related pathogenesis, but to date largely on basis of DNA sequence homology. ${ }^{I}$ The characteristics of the human herpesviruses (HHV) are listed in Table I.

The $\alpha$-herpesviruses have a relatively variable host range, a relative short replication cycle, rapid spread in culture, efficient destruction of infected cells and tendency to establish latent infections in neural tissue. They include HSV-I (HHV-I), HSV-2 (HHV-2) and varicella zoster virus (VZV; HHV-3).

The $\beta$-herpesviruses have a restricted host range. The reproductive cycle is long and the infection progresses slowly in culture. The infected cells frequently become enlarged (cytomegalia). Latency is established in lymphoreticular cells, kidneys and secretory glands. Human $\beta$ herpesviruses include cytomegalovirus (CMV; HHV-5), HHV-6 and HHV-7.

The $\gamma$-herpesviruses have a very restricted host range. Viruses in this group infect specific T- or B-lymphocytes, causing either a lytic or latent infection. Human $\gamma$-herpesviruses include Epstein-Barr virus (EBV; $\mathrm{HHV}-4$ ) and HHV-8.

REPLICATION AND LATENCY OF HERPES SIMPLEX VIRUS (HSV) HSV-I is the prototype of the human herpesviruses. The lytic or productive cycle of infection starts with the attachment of virus particles to susceptible cells. This interaction requires sequential interaction between viral membrane glycoproteins and cellular receptors. Entry of virus mediated by fusion of the envelope and plasma membranes rapidly follows the initial attachment. ${ }^{3}$ Upon entry into the cell, the capsids are transported to the nuclear pores where DNA is released into the nucleus. Transcription of viral DNA takes place in the nucleus in an orderly program. The earliest genes expressed are the five HSV immediate-early genes ( $\alpha$-phase, $2-4$ hours post-infection). They are important in priming the cell for further gene expression and mobilising cellular transcription machinery. This phase is followed by the early gene expression ( $\beta$-phase, 5-7 hours post-infection): the expression of a number of genes either directly or indirectly involved in genome
Fig. 2. Schematic representation of the arrangement of DNA sequences in the HSV genome. ${ }^{2}$

The unique sequences (thin lines) are flanked by the inverted repeats boxes. Letters above the line designate: $\mathrm{a}_{1}=$ terminal $a$ sequence of the unique long component, $\mathrm{a}_{\mathrm{n}}=$ variable number of additional $a$ sequences, $\mathrm{b}=$ the $b$ sequence, $\mathrm{U}_{\mathrm{L}}=$ the unique sequence of the $\mathrm{L}$ component, $\mathrm{b}^{\prime}=$ the repetitions of the $b$ sequence, $\mathrm{a}_{\mathrm{m}}=\mathrm{a}$ variable number of $a$ sequences, $\mathrm{c}^{\prime}=$ the inverted $c$ sequence, $\mathrm{U}_{\mathrm{S}}=$ the unique sequence of the $\mathrm{S}$ component, $\mathrm{c}=$ the repetition of the $c$ sequence, $\mathrm{a}_{\mathrm{s}}=$ the terminal $a$ sequence. 


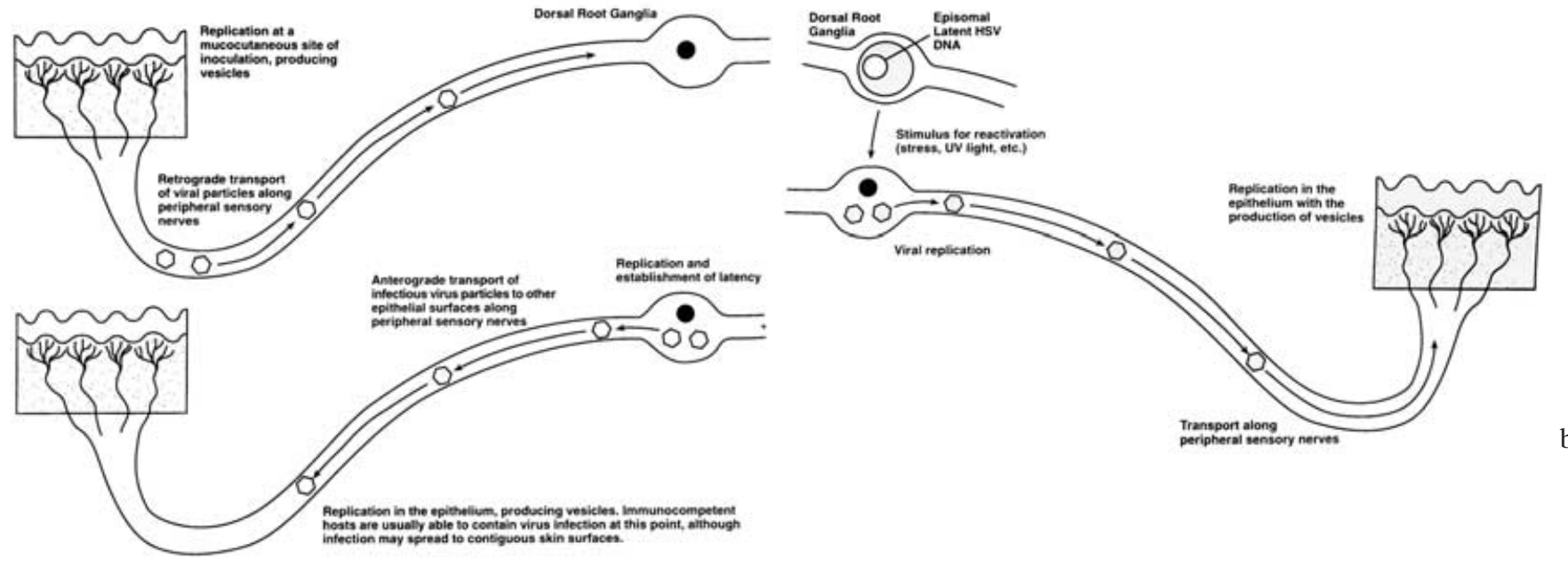

Fig. 3. Schematic diagram of HSV infection, latency and reactivation. Part A, HSV infection and B, HSV latency and reactivation. Figure Reprinted with permission from: Whitley RJ. Herpes simplex viruses. In: Fields BN et al editors. Fields virology, $3^{\text {rd }}$ ed. Philadelphia: Lippincott Raven Publishers I996: 2297-2342. replication. Upon genome replication viral structural proteins are expressed in high abundance during the late phase $(\beta \gamma / \gamma$ phase, timing depends on viral DNA synthesis). Viral capsids assemble in the nucleus. They bud through the host cell nuclear and cytoplasmic membranes, becoming enveloped in the process. Viral proteins are synthesized in the cytoplasm. Some of the host glycoproteins are captured during the process and end up on the outer surface of the virion. Enveloped infectious virions can either remain cell-associated and spread to other cells via virus-mediated fusion, or can be released from the cell for reinfection. 'Cell-to-cell' spread has several important implications for the pathogenesis of the disease. Diseases induced by HSV are characterized by local spread and progression of lesions, thereby largely evading local immune surveillance and host mediated immune clearance. ${ }^{3}$

One of the most striking properties of all herpesviruses is their ability to persist in an apparently inactive state for varying duration of time, referred to as latency. The cellular site of latency appears to be different from the primary tissue in which the lytic infection occurs. HSV combines this property with a tendency for neurovirulence ${ }^{4}$. During primary infection, neurons innervating the infected mucosa are invaded by the virus. After initial infection the HSV ascends by retrograde axonal transport in nerve axons to the innervating sensory ganglia, ${ }^{6,7}$ in which the virus replicates for several days. Subsequently, one of two mutually exclusive events can occur, either viral replication with neuronal destruction, which can result in severe neurological devastation (myelitis or encephalitis), or establishment of a latent infection and neuronal survival (Fig. 3A). Latent infection is defined as a type of persistent infection in which the viral genome is present but infectious virus is not produced except during intermittent episodes of reactivation. During latency little or no virus protein is synthesized, although an untranslated virus transcript, the so-called latency associated transcript (LAT), is produced. Occasionally, latency is interrupted, and the virus reactivates as the result of provocative stimuli. These may include physical or emotional stress, fever, and exposure to ultraviolet light, immune suppression, menstruation and tissue damage. As a con- 
sequence any local trauma can reactivate the virus and cause a manifest infection. ${ }^{4}$ Reactivated virus travels down the sensory nerve and spreads to and replicates in mucocutaneous epithelial cells, producing the characteristic symptoms (Fig. $3 \mathrm{~B}$ ). ${ }^{4}$ Recurrent HSV infections predominantly occur at the site of primary infection.

Latent infections persist for life in the innervating sensory ganglia. ${ }^{8,9}$ Studies of HSV-induced skin diseases reveal that HSV-I is isolated principally from oro-labial lesions innervated by the trigeminal ganglia and that HSV-2 is frequently isolated from lesions in the genital areas innervated by sacral ganglia. However, in addition to these two major sites, HSV can cause latent infection in other sites of spinal ganglia ${ }^{4}$. In addition to ganglionic or neuronal latency, however, there is evidence for persistence of HSV DNA in both the $\operatorname{skin}^{10}$ and the cornea. ${ }^{1 \mathrm{I}, 12, \mathrm{I} 3}$ Expression of LAT, however, has not been detected in these peripheral sites.

Recurrent HSV infections are thought to result mainly from reactivation of the HSV strain (i.e. endogenous strain) acquired during primary infection. ${ }^{\mathrm{I}, \mathrm{I}} \mathrm{I}$ However, genotypic analysis of HSV isolates showed that a target organ is not immune to reinfection. ${ }^{16,17,18,19}$ The reported frequency of reinfection, with an exogenous virus referred to as HSV-I superinfection, in large scale studies seems to be low. ${ }^{20,21,22}$ Recently, we have developed a new PCR method, ${ }^{23}$ based on the stability and strain-to-strain differences of reiterated sequences within the HSV-I genome, to genotype HSV-I strains without viral culture. Evaluation of this technique showed that it provides a discrimination rate of $92 \%$ of unrelated clinical HSV-I isolates. Subsequent genotyping of sequential corneal HSV-I isolates of 30 patients with recrudescent HSV-I keratitis patients demonstrated that the sequential isolates of I I out of 30 patients were genetically different, suggesting corneal HSV-I superinfection in the inter-recurrence period. Furthermore, corneal transplantation was identified as risk factor for corneal HSV-I superinfection. ${ }^{24}$ This finding suggested the possibility of donor-to-host transmission of HSV-I through corneal grafting.

OCULAR MANIFESTATIONS OF HUMAN HERPESVIRUS INFECTIONS (TABLE I) The pattern of clinical disease resulting from primary infection with human herpesviruses is largely determined by the virus involved, the portal of entry and the immune status of the host. Generally in the fully immunecompetent host both primary and recurrent infections cause mild or no symptoms. ${ }^{4}$ When clinical symptoms do occur, they range from the common fever blisters on the lip to more rare and severe infections of the central nervous system. An overview of clinical manifestations of HHV infections is given in Tables I and 2 and Figure 4. Immunecompromised persons, e.g. transplant recipients, neonates and AIDS patients, are at increased risk for severe herpesvirus infections.

Of the eight human herpesviruses identified to date seven have been shown to have clinical implications for ocular infection. HSV-I and VZV are the viruses that cause eye disease most frequently. ${ }^{25,26}$ Not only the eye proper, may be affected, also infections of the adnexae, 


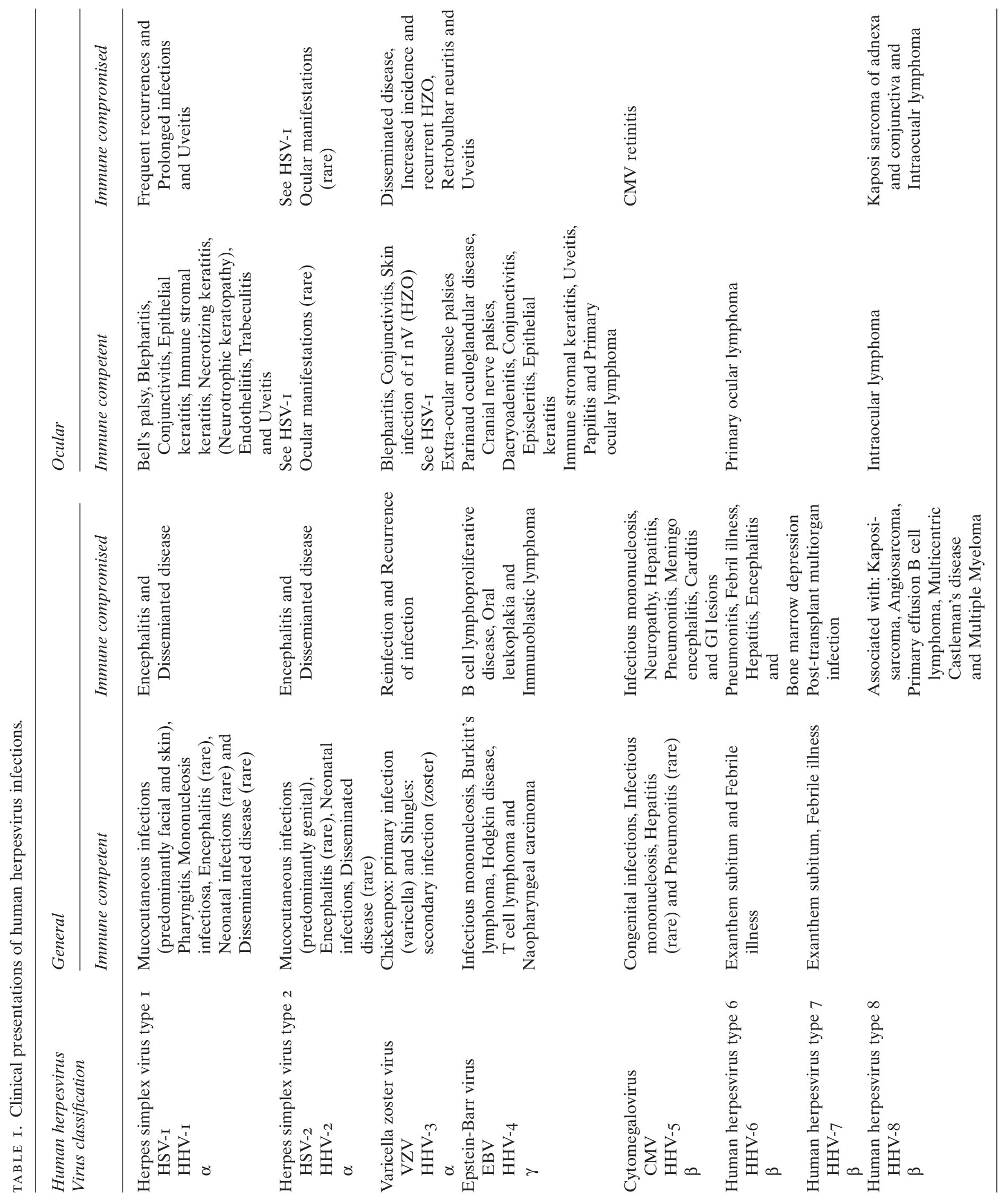




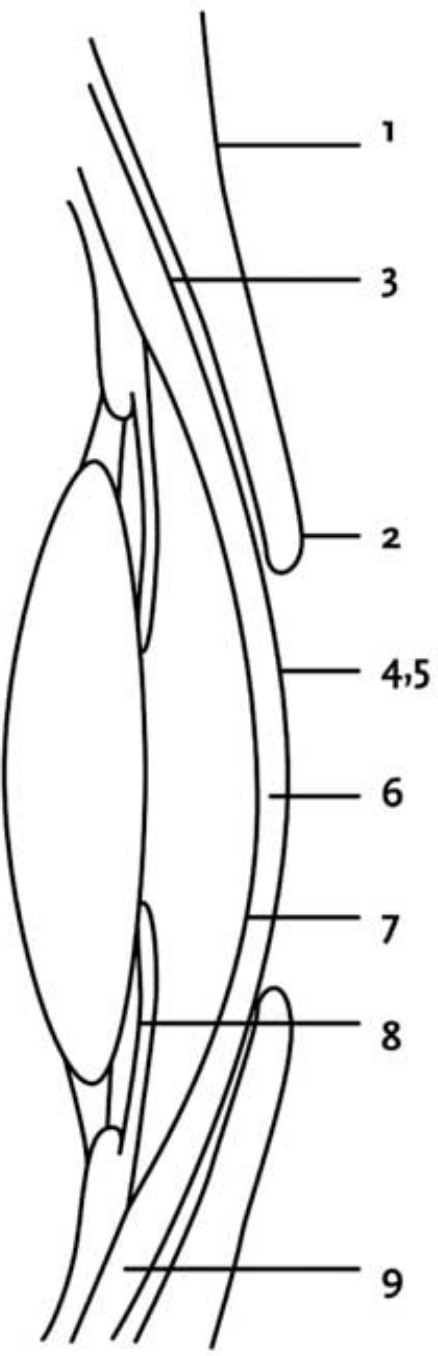

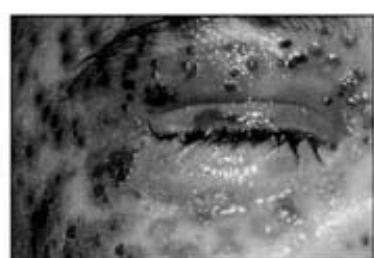

ı: Periocular dermatitis

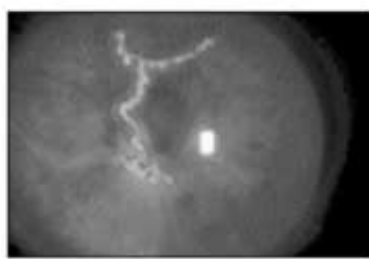

4: Infectious epithelial keratitis (dendritic keratitis)

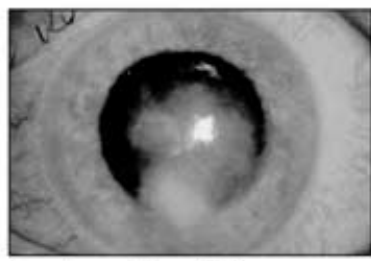

6a: stromal keratitis Immune stromal keratitis

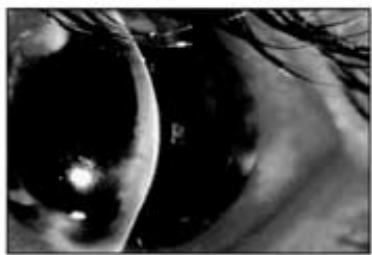

7: Endotheliitis

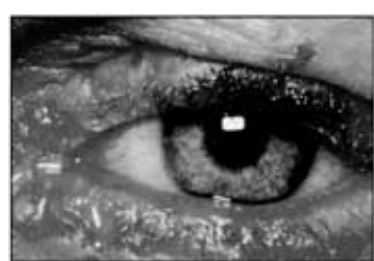

2: Blepharitis

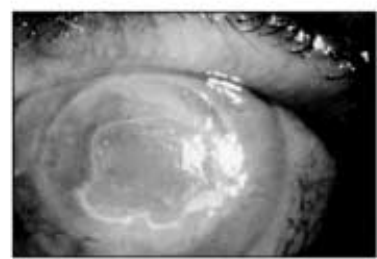

5: Neurotrophic keratitis

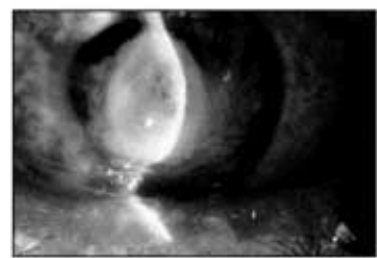

6b: stromal keratitis Necrotizing stromal keratitis

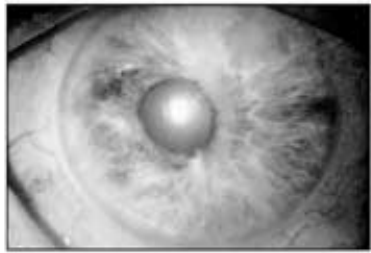

8: Uveitis

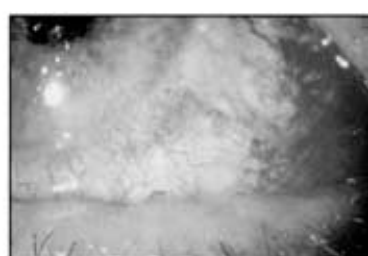

3: Conjunctivitis (with ulceration)

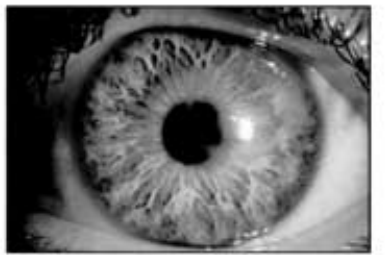

6c: stromal keratitis

Immune ring

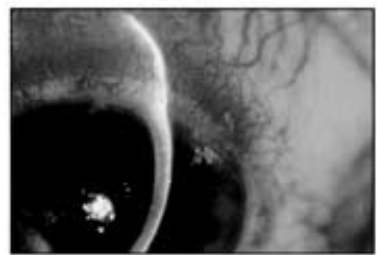

9: (Epi-)scleritis like the eyelid skin and lacrimal gland, as well as infections of the cranial nerves ${ }^{27}$ are possible. HSV-2 infections of the eye are relatively rare, with clinical manifestations identical to those of HSV-I.

Primary and recurrent HSV infections in immunecompetent patients predominantly present with vesicular or ulcerating lesions on skin or mucous membranes. The mouth and lips are the most common sites of HSV-I infection. Reactivation of herpesviruses is common in the immunecompromised host, usually resulting in asymptomatic viral shedding or in progressive mucocutaneous infection. HSV can disseminate and cause diffuse visceral infection. ${ }^{28}$ Varicella, caused by primary infection with VZV, is a common childhood infection. Ocular involvement in varicella frequently occurs on the eyelids, whereas corneal involvement is uncommon. Recurrent VZV infection (herpes zoster) presents as a cluster of vesicular lesions, so-called shingles, which appear unilaterally in the dermatomal distribution of one or more adjacent sensory nerves. ${ }^{29}$ Herpes zoster ophthalmicus is a clinical syndrome involving the ophthalmic branch of the trigeminal nerve. Ocular complications occur in $50-72 \%$ of patients with herpes zoster
Fig. 4. Presentations of herpes simplex virus infections of the anterior eye segment.

Adapted from: Sundmacher R. A clinico-virologic classification of herpetic anterior segment diseases with special reference to intra-ocular herpes. In herpetische Augen Erkrnakungen DOG I980. Eds R. Sundmacher. München: JF bergmann verlag I98I:206. 
ophthalmicus. ${ }^{30}$ In case of VZV infections of the eye the same clinical manifestations as in HSV-I infections are possible. In addition to these manifestations, postherpetic neuralgia and cranial nerve palsies may occur. ${ }^{31}$ Ocular disease caused by the reactivation of latent VZV is more likely to occur in the elderly and the immune compromised. ${ }^{32,33,34,35}$

EBV is the most common etiologic agent of infectious mononucleosis. ${ }^{36} \mathrm{EBV}$ is also associated with malignant disease, including different types of lymphomas and nasopharyngeal carcinoma. ${ }^{36,37}$ Ocular manifestations occur rarely in EBV infection. When present, they may encompass a wide range of clinical pictures, including infections of the anterior segment of the eye,$^{38}$ neuro-ophthalmological syndromes ${ }^{39}$ and intra-ocular lymphoma. ${ }^{40}$

Congenital infections with CMV primarily affect the reticuloendothelial system and the central nervous system (CNS), whereas acquired CMV infection in immunecompetent individuals is usually asymptomatic. Some patients, however, develop a syndrome resembling infectious mononucleosis. Progression to invasive organ disease is mainly seen in immunecompromised patients. ${ }^{4 \mathrm{I}}$ Ocular manifestations are rarely seen in congenital CMV infections. Ocular involvement in CMV infections in the adult population is confined to immunecompromised patients. In this group CMV is a common cause of retinitis. ${ }^{42}$

The more recently discovered human herpesviruses, HHV-6 and HHV-7 have been associated with febrile illnesses and the childhood disease, exanthema subitum. ${ }^{43}$ In immunecompromised patients the spectrum of disease is extended to solid organ infections and bone marrow depression. ${ }^{44}$ To date HHV-7 has not been associated with ocular disease. Clinically manifest infections with HHV-8 are predominantly seen in immunecompromised patients. This virus seems to resemble EBV in its possible oncogenic properties. ${ }^{45}$ In isolated cases HHV-6 and HHV-8 are associated with intraocular lymphomas..$^{40,46}$

Epidemiology of HSV infections Herpesviruses do not persist well on environmental surfaces, and infection needs direct inoculation into areas where they can replicate. The first line of defense against the virus is the keratin layer of the superficial epidermis, which prevents direct access of these viruses to cell-membranes. In the absence of keratin, for instance in mucous membranes, cells are more prone to be infected. ${ }^{47} \mathrm{HSV}$-I can be transmitted following close contact with the secretions, skin, or mucous membranes of a person shedding virus. Infection occurs via the mucosal surfaces. Infections with HSV-2 are usually acquired through sexual contact.

Humans are considered to be the only natural reservoir of HSV. HSV infects its host generally in the first decades of life. ${ }^{4}$ Primary infections with HSV manifest clinically only in $\mathrm{I}-6 \%$ of the time ${ }^{48}$ and most episodes of clinical disease are manifestations of reactivation of HSV infection. Because only a third of the individuals who harbor HSV recognize disease symptoms during primary or recurrent infections, serologic studies are used to defining the prevalence of HSV infections in the population. Seroprevalence rates of HSV vary with age, sex, sexual behavior, socio-economic status and geographic location. ${ }^{49}$ In adult populations the prevalence of HSV-I antibodies varies from $45 \%{ }^{50}$ to 


\begin{tabular}{llc}
\hline Clinical manifestation & $\begin{array}{l}\text { Initial clinical } \\
\text { disease } \%\end{array}$ & $\begin{array}{c}\text { Recurrent } \\
\text { disease } \%\end{array}$ \\
\hline Blepharitis $^{68,69,176,177}$ & $38-54$ & $4-20$ \\
Conjunctivitis $^{68,69,176,177}$ & $54-84$ & $4-20$ \\
Epithelial keratitis (dendritic) $^{68,69,176,177}$ & $\mathrm{I} 5-63$ & $47-60$ \\
Stromal keratitis (ISK $\left.^{+} \mathrm{NSK}\right)^{68,69,176,177,178}$ & $2-6$ & $20-48$ \\
(Kerato-)uveitis $^{68,176}$ & 4 & $\mathrm{I}$ \\
Acute retinal necrosis & & $<0.0000 \mathrm{I}$ \\
Others & $<0.0000 \mathrm{I}$ & $<0 . \mathrm{I}$ \\
\hline
\end{tabular}

$88 \% .^{49,51,52}$ Corresponding with seroprevalence $70-80 \%$ of healthy individuals have HSV-IDNA in their trigeminal ganglion. There is a trend towards a decreasing incidence of HSV-I infections in the developed world. ${ }^{49,53,54}$ Antibodies to $\mathrm{HSV}-2$ are rarely found before ages of onset of sexual activity. There is a trend towards an increasing incidence of HSV-2 infections in both the developed and developing countries. ${ }^{49,50,55}$ Although most genital HSV infections are caused by HSV2 infection, a recognizable and growing portion is attributable to HSV-I infections. ${ }^{56}$

Among recipients of organ transplants, transmission of viruses through donor tissues is a well recognized clinical problem. CMV is the most prominent example. Manifest infection may occur, besides from reactivation, by graft-to-host transmission of donor-derived virus as a result of transplantation. Though rare, there are reports demonstrating probable HSV transmission to seronegative organ transplant recipients. ${ }^{57.58}$ Corneal transplantation is the most common type of tissue transplantation in The Netherlands. It is usually a safe procedure with little associated morbidity. In $5-10 \%$ of these patients herpetic keratitis is the reason for penetrating keratoplasty (PKP). ${ }^{59}$ Herpetic keratitis recurs relatively frequently (I0-20\%) after PKP. After PKP for reasons unrelated to HSV infection patients may still develop herpetic keratitis in their graft, ${ }^{60,61,62,63}$ referred to as 'newly acquired HSV keratitis after PKP'.

EPIDEMIOLOGY OF OCULAR HSV-I INFECTION Ocular HSV infections are mainly confined to the anterior segment of the eye, including the conjunctiva and the eyelids (Table 2). HSV appears to be the most common infectious cause of blindness in developed countries. ${ }^{64}$ In developing countries, where chlamydia conjunctivitis is endemic, it is only second to trachoma as a cause of corneal blindness. In malnutrition combined with measles infection, HSV keratitis is a common cause of bilateral corneal blindness in children in the developing world. ${ }^{65}$ Despite the common exposure to HSV, ocular manifestations are only observed in about I \% of those exposed. This may be an underestimation because presenting symptoms of blepharitis and conjunctivitis are mild, and the condition remains largely unrecognized. Only 5\% of ocular HSV disease represent primary infections. ${ }^{66}$ Liesegang et al. reported an incidence of 8.4 first ocular HSV infections per 100,000
TAв LE 2. Prevalence of clinical manifestation in individuals suffering from ocular HSV infection. 
TABLE 3. Complications in corneal allografting associated with HSV-I

\begin{tabular}{|c|c|c|c|c|c|}
\hline \multirow[t]{2}{*}{ Complication after PKP } & \multicolumn{2}{|c|}{$\begin{array}{l}\text { data for general } \\
\text { corneal transplant } \\
\text { population }\end{array}$} & \multicolumn{2}{|c|}{$\begin{array}{l}\text { graft failure } \\
\text { associated } \\
\text { with } H S V-I\end{array}$} & \multirow[t]{2}{*}{ Method } \\
\hline & $n$ & $\%$ & $n$ & $\%$ & \\
\hline $\begin{array}{l}\text { Newly acquired HSV-I after } \\
\text { PKP }\end{array}$ & $\mathrm{I} 8 / 2 \mathrm{II} 2^{75}$ & 0.9 & $\mathrm{I} 4 / 25^{180}$ & 56 & viral culture \\
\hline Corneal allograft rejection & $29 \mathrm{I} / 3048^{71}$ & 9.5 & $\begin{array}{l}8 / \mathrm{I} 7^{169} \\
3 / \mathrm{I} 7^{169}\end{array}$ & $\begin{array}{l}47 \\
\text { I } 8\end{array}$ & $\begin{array}{l}\text { PCR } \\
\text { GwC }\end{array}$ \\
\hline $\begin{array}{l}\text { Primary graft failure } \\
\text { Extreme endothelial cell loss } \\
\text { in cell culture }\end{array}$ & $\begin{array}{l}215 / 10363^{181} \\
7 / 1205^{71}\end{array}$ & $\begin{array}{l}2 . \mathrm{I} \\
0.6\end{array}$ & $\begin{array}{l}2 / 3^{182} \\
9 / 199^{172} \\
7 / 199^{172}\end{array}$ & $\begin{array}{l}66 \\
4 \cdot 5 \\
3 \cdot 5\end{array}$ & $\begin{array}{l}\text { PCR } \\
\text { PCR } \\
\text { viral culture }\end{array}$ \\
\hline
\end{tabular}

person-years. ${ }^{67}$ The overall prevalence of ocular HSV infection has been estimated at I49 cases per I00,000 person-years. ${ }^{67}$

Blepharitis, conjunctivitis and epithelial keratitis are the most common symptoms of primary ocular HSV infections. The predominant form of recurrent disease is epithelial and stromal keratitis (Table 2 ). Disease is bilateral in $\mathrm{I} 2-\mathrm{I} 9 \%{ }^{68,69}$ of cases. A history of epithelial keratitis is not a significant risk factor for recurrent epithelial keratitis, whereas previous multiple episodes of stromal keratitis markedly increase the probability of subsequent stromal keratitis..$^{70}$ The interval between attacks shortens with time. ${ }^{68}$ Herpetic stromal keratitis is a leading infectious cause of blindness worldwide. ${ }^{67}$

PENETRATING KERATOPLASTY (PKP) AND HSV KERATITIS In the general population, ocular manifestations of HSV-I infection can lead to unilateral blindness and as result an indication for PKP. Five to I0\% of PKPs are performed for corneal opacities resulting from HSV-I infection. ${ }^{71}$ PKP for HSV keratitis has a high rate of post-operative complications (Table 3). Epithelial recurrences are a major problem after PKP. Graft rejections contribute to graft failure to a larger extent in PKP for HSV than in PKP for reasons unrelated to HSV-I infection. ${ }^{72}$ Recurrences of HSV keratitis after PKP and the rate of immunological graft rejection in these grafts can be reduced by antiviral prophylaxis when steroids are employed to prevent or treat graft rejection. ${ }^{73}$ However, the use of prophylactic antiviral therapy is largely based on experience in patients with recurrent HSV related eye disease who have not undergone PKP. ${ }^{74}$

NEWLY ACQUIRED CORNEAL HSV-I INFECTIONS AFTER PKP The finding, that HSV-I keratitis occurs after PKP in patients without a previous history of HSV keratitis, poses questions about the frequency and impact of this manifestation, about the mode of transmission in these patients, and which transplant recipients are at risk to develop this infection.

In a retrospective analysis among 2 II 2 patients transplanted for reasons unrelated to HSV infection, I8 presented with HSV-I epithe- 
lial keratitis in their graft. ${ }^{75}$ The incidence of newly acquired HSV keratitis after PKP was calculated to be I.2 per I000 person years, i.e.I4-fold higher than that observed in the general population. ${ }^{76} \mathrm{~A}$ recent study conducted in 25 patients with this clinical manifestation, indicated that the majority of them $(n=I 4)$ developed severe ocular complications resulting in social blindness of the infected eye within three years (L. Remeijer; unpublished observation). In most cases, the newly acquired HSV-I infection occurs within the first two years after PKP, again suggesting a causal relationship between corneal transplantation and HSV-I infection. Several possibilities as to the origin of the virus exist, such as reactivation of latent virus in the trigeminal ganglion, viral transmission through tear shedding, viral growth in the storage medium or transmission through the donor cornea. Infectious agents that have been shown to be transmitted following corneal transplantation include bacteria, fungi, Creutzfeldt-Jakob agent, hepatitis B and $\mathrm{C}$ viruses and rabies virus. ${ }^{77}$

Transmission of HSV-I through corneal transplantation has recently been demonstrated by genetic characterization of HSV-I DNA isolated from a donor cornea before and after corneal transplantation. ${ }^{78}$ The DNA sequences were identical for both strains. The patient proved to be HSV-I naive before the transplantation.

Host immune response to HSV Following a viral infection, the immune system will recognize the virus as a foreign entity and try to eliminate it from the host. At first, non-specific immune cells, including macrophages, polymorphnuclear cells (PMN) and natural killer (NK) cells, which are part of the innate immune system, are attracted to the site of infection. Secondly, a virus-specific immune response (i.e. adaptive immunity) develops in which both $\mathrm{B}$ and $\mathrm{T}$ lymphocytes are involved. This constellation of immune responses to the virus serves to protect the infected organism from disseminated viral disease and death. $^{79}$

INNATE IMMUNE RESPONSE The first line of defense against herpesviruses is formed by the innate immune system. This system consists of cellular and soluble components. Macrophages and PMN recognize viral antigens in a non-specific fashion and eliminate the virus by phagocytosis and subsequent intracellular degradation. Both cell types show a marked increase of uptake of virus when virions are opsonized by antibody or complement ${ }^{80}$ The anti-viral effect of NK cells involves the lysis of viral infected cells and production of IFN- $\gamma$ upon stimulation with other cytokines like interleukin I2 (IL-I2). The recognition of a virus-infected cell by NK cells is mediated either by the opsonization of an infected cell by virus-specific antibody, ${ }^{8 \mathrm{I}}$ or by antigen recognition independently of the histocompatibility complex (MHC).$^{82}$ Herpesvirus infection results in down-regulation of MHC class I molecules at the surface of an infected cell, rendering the cell susceptible to NK cell killing. ${ }^{83}$ Low NK cell activity is linked with increased human sensitivity to disseminated herpesvirus infections, including those with HSV, EBV and CMV. ${ }^{81,82}$ Cells of the innate immune system are located 
in large numbers at strategic sites in and behind the physical barrier of the organism, or circulate through the body fluids awaiting attraction to the site of infection by chemotaxis.

The complement system and cytokines/chemokines secreted by virus infected cells and inflammatory cells, form the major soluble component of the innate immune response to herpesvirus infection. Viral infection directly stimulates the production of IFN $\alpha$ and $\beta$ by infected cells. Both IFN $\alpha$ and $\beta$ inhibit viral replication, ${ }^{84}$ enhance the ability of NK cells to kill infected target cells ${ }^{79}$ and facilitate antigen processing and presentation by MHC. ${ }^{82}$ The secretion of various chemokines, like IL-8, is induced at sites of viral infection providing a chemotactic signal for immune cells to infiltrate the affected tissue.

This first line of immune defense facilitates an immediate response to invading infectious agents, irrespective of the site of entry. Moreover, it will limit dissemination of the virus, while at the same time the development of a specific immune response in the draining lymphoid tissues is initiated to combat the remaining virus and to build up immunological memory.

ADAPTIVE IMMUNE RESPONSE Specific immune responses are mediated by lymphocytes, recognizing the antigen by specific membrane-bound antigen receptors. The adaptive immune response can be divided into a humoral and a cellular immune response, mediated by $\mathrm{B}$ and $\mathrm{T}$ lymphocytes, respectively.

Humoral immunity Virus-specific antibodies are important in the defense early in the course of viral infection and in defense against viruses that are liberated from lysed cells. Within several days after onset of a herpesvirus infection, antibodies to some of the viral proteins appear in the circulation. The major immunogens of HSV are the viral proteins expressed at the cell surface of infected cells: the glycoproteins. ${ }^{85,86}$ Neutralizing virus-specific antibodies bind to envelope proteins and prevent viral attachment and entry into host cell. Opsonizing antibodies may enhance phagocytic clearance of viral particles. Secretory immunoglobulins of the $\operatorname{IgA}$ isotype, i.e. $\operatorname{SgA}$, may be important for neutralizing viruses that enter via the mucous membranes and trigger complement-mediated lysis of infected cells. ${ }^{79}$ Infectious cellfree virus is mainly detected during primary infection. Herpesviruses like HSV have a cell-to-cell spread and survive latently in the sensory neurons, being inaccessible to antibodies after entry in the cell. In HSV infection, antibodies do play a role in limiting dissemination the virus from the primary site of infection to the innervating sensory ganglia and other parts of the nervous system. ${ }^{87,88}$ Severe cases of herpesvirus infections have been described in antibody deficiency syndromes, indicating that antibodies are an important component in the immune response to HSV infection. ${ }^{87}$

Cellular immunity Severe HSV infections in patients with impaired T cell immunity, e.g. AIDS patients and transplant recipients, indicate that these cells play an important role in controlling viral infection. ${ }^{89}$ Both virus-specific $\mathrm{CD}_{4}^{+}$and $\mathrm{CD}^{+} \mathrm{T}$ cells are mandatory in controlling her- 
pesvirus infection. They distinguish virus-infected from non-infected cells by their $\mathrm{T}$ cell receptor, recognizing virus-derived peptides associated with MHC class II or I molecules expressed at the cell surface of infected cells, respectively. ${ }^{79}$ Following activation, T cells can kill infected cells or secrete cytokines. Based on their cytokine production profile, $\mathrm{T}$ cells can be divided into two groups: TI and T2 cells. TI cells mainly secrete IL-2, IFN- $\gamma$ and TNF- $\alpha$, whereas secretion of IL-4, IL-5 and IL-IO is restricted to T2 cells. The subgroup of T cells referred to as To cells secrete both $\mathrm{T}_{\mathrm{I}}$ and $\mathrm{T} 2$ cytokines. In general herpesvirusspecific $\mathrm{T}$ cells responses are both $\mathrm{T}_{\mathrm{I}}$ and To-like.

IMMUNE EVASION Herpesviruses have evolved numerous strategies that favor their own survival by evading host immunity. These strategies fall into two categories: indirect immunomodulatory effect of viral proteins by their interaction with the protein machinery of the host cell and the direct inhibitory effect of viral encoded proteins. Upon herpesvirus infection, virus-specific $\mathrm{CD} 8^{+} \mathrm{T}$ cell recognition is hampered by the low level of MHC class I expression on infected cells. Several herpesvirus proteins, like infected cell protein (ICP) 47 of HSV-1, have been shown to inhibit the assembly and cell surface expression of stable MHC class I molecules. ${ }^{90}$ Recently, ICP 22 of HSV-1 has been shown to inhibit $\mathrm{CD}^{+} \mathrm{T}$ cell responses. ${ }^{91}$ Additionally, herpesviruses are able to prevent apoptosis of infected cells. ${ }^{92}$ Some herpesviruses produce molecules that directly inhibit innate and adaptive immune responses. For example, human CMV encodes a protein (UL18), that inhibits T1/0 responses and is homologous to MHC class I proteins, which acts as a decoy for NK cells ${ }^{93}$ and an EBV protein, that shows homology to IL$10 .^{90}$ Furthermore, three glycoproteins of HSV modulate the innate immune response by binding to complement factor $3 \mathrm{~b}(\mathrm{gC})^{94}$ or the humoral response by binding to the $\mathrm{Fc}$ portion of $\mathrm{IgG}$ molecules (complex of $\mathrm{gE}$ and $\mathrm{gI}){ }^{95}$

IMMUNOPATHOLOGY An immunopathogenic response is an immune response that causes tissue damage. This can occur when cells are destroyed with a limited regenerative capacity, or when repair deposits impair the function. ${ }^{96}$ Several mechanisms of immunopathology have been described. A consequence of persistent infection with some viruses is the formation of circulating immune complexes composed of viral antigens and specific antibodies. These complexes may become trapped in tissues and trigger inflammatory responses in which complement and PMNs play a major role. ${ }^{96}$

During an immunopathogenic response the immune reaction changes focus with time, beginning with an appropriate antiviral response and spreading to encompass host antigens. Some viruses are known to contain amino-acid sequences that are also present in some self-antigens. It has been postulated that because of this 'molecular mimicry' antiviral immunity can lead to immune responses against self-antigens. The virus antigen should be different enough from host sequences to initiate an immune response, but similar enough that the response is cross-reactive. The resulting 'anti-host' response will then be maintained even after clearance of the virus. ${ }^{97}$ Alternatively, virus 
Fig. 5. Architecture of the human cornea.

Photograph of a cross section of a healthy human cornea. ep, epithelium; B, Bowman's layer; s, stroma; D, Descemet's membrane and en, endothelium.

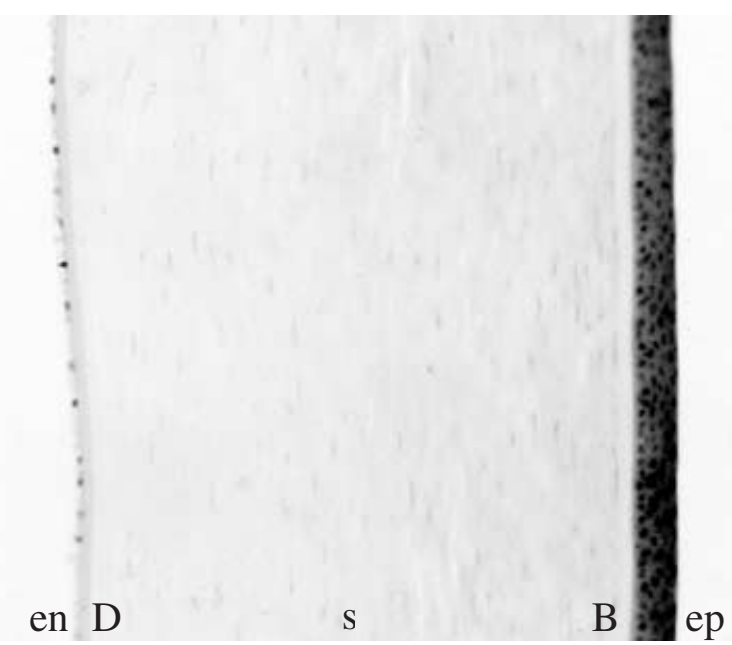

infection may induce autoimmunity in the absence of shared antigens, a mechanism known as 'bystander activation'.

\section{Herpesvirus keratitis}

CORNEAL MORPHOLOGY AND INNERVATION The cornea is the transparent tissue in the front of the eye that is primarily responsible for focusing light on the retina. The central cornea is about $0.52 \mathrm{~mm}$ thick. The tissue comprises five layers: epithelium, Bowman's layer, stroma, Descemet's membrane, and endothelium (Fig. 5). In the normal state the cornea does not contain blood vessels. ${ }^{98}$

The corneal epithelium is a stratified squamous, non-keratinizing epithelium, approximately five cell-layers thick. Epithelial cells adjacent to Bowman's layer can divide and renew the epithelial layer in two to four days. Epithelial wounds heal quickly over an intact Bowman's layer. The Bowman's layer is a very thin $(8-\mathrm{IO} \mu \mathrm{m})$ acellular zone beneath the epithelium. Bowman's layer is often said to be resistant to trauma, offering a barrier to corneal invasion by microorganisms and tumor cells, but it is not known to which extent this is true. The Bowman's layer is considered to have no regenerative capacity. The stroma that constitutes about $90 \%$ of the cornea consists mainly of collagen fibrils, ground substance and keratocytes. The collagen fibrils of the cornea are uniform and small, about $250-300 \AA$ in diameter. The ground substance surrounding the collagen fibrils is rich in glycosaminoglycans. The ground substance plays a role in maintaining the regular array of collagen fibrils. With stromal edema the individual collagen fibril does not change, the volume of the ground substance increases, and with this the space between collagen fibrils. The keratocyte is the predominant cell of the stroma, but accounts only for about $5 \%$ of the dry weight of the cornea. In response to stromal injury the keratocytes migrate into the wound area and undergo transformation into myofibroblasts. They contribute to the scar formation by proliferation and collagen production. The Descemet's membrane is produced by the endothelium and approximately Io $\mu \mathrm{m}$ thick. The endothelium is a monolayer of regularly shaped hexagonal cells, lying posterior on 


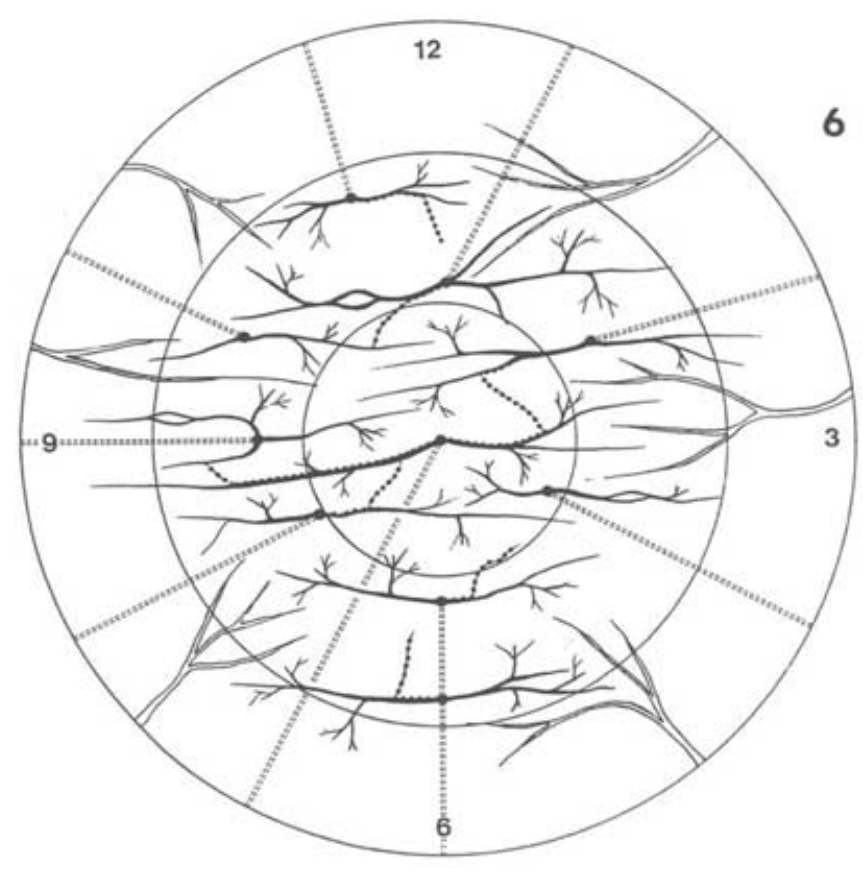

Descemet's membrane. The main function of the corneal endothelium is control of stromal hydration. This is essential for corneal transparency. Endothelial cells generally do not show mitotic activity. Cell density below a critical number $\left(400-600\right.$ cells $\left./ \mathrm{mm}^{2}\right)$ is devastating for the transparency of the cornea..$^{8}$

Sensory innervation of the cornea is supplied by the ophthalmic branch of the trigeminal nerve (ramus I, nervus V). The nerve fiber pattern of the cornea has been described as radially oriented nerve bundles entering the cornea from the sclera at the middle one third of its thickness..$^{98}$ The nerves lose their myelin sheath after traversing $0.5-2.0 \mathrm{~mm}$ into the cornea and then continue as transparent axon cylinders. After passing Bowman's layer, they ramify and end within the epithelium as free nerve endings. ${ }^{99,100}$ The nerve bundles in the subbasal plexus of the human cornea form a regular dense meshwork with equal density over a large central and mid-peripheral area ${ }^{\mathrm{IOI}}$ (Fig. 6).

THE CORNEA: AN IMMUNE PRIVILEgED SITE The cornea is considered to be an immune privileged tissue, in part because it cannot directly be accessed by the immune system: ${ }^{102}$ the cornea lacks blood and lymphatic vessels, structures that provide the conduit for transportation of immunologic components into and out of most tissues. ${ }^{103}$ The absence of blood vessels leads to sequestration of corneal antigens from the circulation. However, the normal cornea contains professional antigen presenting cells (APCs) such as dendritic cells and macrophages. ${ }^{104}$ Factors present in the normal cornea that contribute to immune privilege are IL-I receptor antagonist and Fas ligand. Both are constitutively expressed and promote ocular immune privilege by different pathways. ${ }^{105,106}$ The cornea is in close contact with the fluid of the anterior chamber of the eye. Several mechanisms play a role in the
Fig. 6. Sensory innervation of the cornea: the subbasal nerve plexus of the epithelium.

Nerve fiber bundles in the subbasal plexus of the human cornea run first in the 9 to 3 hours direction. After the first bifurcation they run in the I2 to 6 hours direction and after the second bifurcation they run again in the 9 to 3 hours direction. The beaded fibers run singly and obliquely after branching. Reprinted with permission from: Müller LJ, et al. Architecture of human corneal nerves. Invest Ophthalmol Vis Sci. I997;38:985-994. 
immune privilege of the anterior chamber: blood-ocular barrier, the absence of lymphatic drainage from the intraocular structures, deviant host immune response after introduction of antigens (aqueous chamber associated immune deviation: ACAID) and soluble factors in the aqueous humor having a immunosuppressive effect on APC and T cells. ${ }^{107,108}$

Although the cornea is an immune privileged site, the complete immune apparatus is present in the iris and at the limbus, a tissue that constitutes the zone between the cornea and surrounding conjunctiva. The conjunctiva has a rich lymphatic network arising approximately I mm peripherally from the limbus. During the course of inflammation Langerhans' cells (dendritic cells) migrate from the limbus into the central cornea and the blood-ocular barrier can break down. In chronic inflammation the cornea becomes vascularized and thus the immune privileged state can be lost. ${ }^{103}$ Moreover, early in the inflammatory process, leukocytes extravasate from blood vessels in the limbus and migrate towards the center of the cornea.

Corneal HSV infections: clinical features HSV keratitis ranges from a superficial inflammation of the cornea to a complex ocular disease. It is usually initiated by the cytopathic effect of the virus and followed by inflammatory responses, which may affect all layers of the cornea. The ocular sequelae of HSV infections are determined by the frequency and duration of the recurrent disease episodes and the immunological response elicited. The four main categories of HSV keratitis $^{\mathrm{I09,II0}}$ are infectious epithelial keratitis (IEK), neurotrophic keratopathy, herpetic stromal keratitis (HSK), and endotheliitis. Each of these is subdivided into more specific clinical presentations (See Fig. 4).

infectious epithelial KeRAtitis The earliest epithelial lesions of HSV infection in the cornea are small vesicles in the epithelium, ${ }^{\text {III }}$ which have also been described as punctate epithelial keratopathy. ${ }^{112}$ Vesicles coalesce and a branching, linear lesion with terminal bulbs (swollen epithelial borders) develops, leading to the most common presentation of HSV keratitis: dendritic keratitis. The morphological features of epithelial HSV infection are in part due to contiguous cellto-cell spread of the virus in the corneal epithelium restricted only by local immune surveillance. ${ }^{\mathrm{II}, \mathrm{II} 4}$ This 'contiguous cell-to-cell spread', however, does not explain the branching pattern of the dendritic corneal lesion: an almost circular corneal lesion would theoretically have been developed. It seems logical to postulate that HSV, with its affinity for neural tissue, causes lesions congruent with the anatomical pattern of innervating nerves of the target-organ. The nerve bundles in the subbasal plexus of the human cornea form a regular dense meshwork with equal density over a large central and mid-peripheral area. These nerve fiber bundles in the subbasal plexus run in the 9 to 3 hours direction just after penetrating the Bowman's layer, then after the first bifurcation in the 12 to 6 hours direction and after a second bifurcation again in the 9 to 3 hours direction ${ }^{\text {IOI }}$ (Fig. 6). The branching pattern and the orientation of the dendritic lesion in HEK correlate with the 
anatomy of the subbasal nerve plexus in the human corneal epithelium. ${ }^{I 5}$ In the borders of the lesion infectious virus may be present. As the disease process continues the center ulcerates and extends through the basement membrane. ${ }^{\mathrm{II}}$ An enlarged dendritic ulcer, that is no longer linear, is referred to as a geographic ulcer. Another manifestation of IEK is the marginal ulcer. The proximity of the limbus leads to a rapid infiltration of leukocytes and neovascularization. The ulcer may lack the typical dendritic shape. ${ }^{117}$

NeURotrophic KeRAtitis Multiple episodes of herpetic disease can result in structural injury to the Bowman's layer and corneal stroma. Early findings include irregularity of corneal surface and lack of normal luster. Punctate epitheliopathy may progress to a persistent epithelial defect, oval shaped with smooth grayish borders. ${ }^{109,110}$ Untreated or mistreated lesions may progress into ulceration, opacification, vascularization, and perforation of the cornea.

HERPETIC STROMAL KERATITIS The corneal stroma may be affected as result of a corneal HSV infection through a variety of mechanisms. Stromal keratitis is a more severe and prolonged manifestation of HSV disease and occurs when the virus initiates a chronic corneal inflammation. It can be classified as immune stromal keratitis (ISK) and necrotizing stromal keratitis (NSK). ${ }^{109,110}$ These two manifestations are not mutually exclusive and probably a continuum.

Immune stromal keratitis may present as superficial stromal scarring or the so called 'ghost scars', deeper located infiltrative stromal keratitis. A rare form of ISK is a white ring shaped stromal lesion or the socalled immune ring. The inflammatory response results in cellular infiltrate, edema, neovascularization and corneal scarring as a result of fibrosis and tissue destruction.

The predominant feature of NSK is necrosis with tissue loss, often masked by edema in the active phase of the inflammation. The clinical picture can evolve rather quickly and is sometimes refractory to treatment. The edema and neovascularization are more pronounced compared to ISK. Corneal scarring often leads to irregular astigmatism that may strongly interfere with vision.

CORNEAL ENDOTHELIITIS Corneal endotheliitis is an inflammatory reaction at the level of the corneal endothelium. In isolated endotheliitis stromal infiltrate and neovascularization are absent. Patients characteristically have keratic precipitates (KP), stromal and epithelial edema, and mild iritis. HSV endotheliitis can be classified based on the distribution of the KP and the configuration of the overlying stromal and epithelial edema. ${ }^{109}$ The most common form is disciform endotheliitis. Diffuse and linear forms of endotheliitis are also observed. ${ }^{18,119}$ When inflammation persists or is left untreated, secondary neovascularization and scarring may occur. Chronic endotheliitis may lead to endothelial decompensation.

Herpes Keratitis After penetrating Keratoplasty Herpesvirus infection in a corneal graft may present with the whole range 
of manifestations as in non-operated eyes. Early after transplantation IEK may present as a large epithelial defect without the characteristic dendritic appearance. ${ }^{120}$ In addition to this, herpetic keratitis might present with the manifestations of an allograft reaction: from a linear endotheliitis resembling a Khodadoust line ${ }^{\mathrm{II} 9}$ to a diffuse endotheliitis, indiscernible from a full blown graft rejection. ${ }^{\mathrm{I20}}$

Corneal HSV infections: diagnosis Traditionally the diagnosis of HSV keratitis is based on history and clinical presentation, occasionally complemented by viral culture. Viral isolation in cell culture remains the standard for the detection of infectious virus. This technique is not always available in general ophthalmology practice. Viral culture is an insensitive technique, particularly for the isolation of HSVI from the deeper layers of the cornea. Cultures are only found positive in herpetic keratitis with an epithelial defect. The polymerase chain reaction (PCR) represents a sensitive research laboratory tool and has the advantage of detecting very small amounts of DNA or RNA. The detection of HSV DNA by PCR provides evidence for the presence of viral DNA, which not necessarily means the presence of infectious virus.

Many lesions may present with a dendritic or dendriform lesion, including the epitheliopathy seen in healing corneas after a dendritic ulcer, a healing corneal abrasion, and the early stages of acanthamoeba keratitis. In ISK many other causative agents of infection are possible. However, $66 \%$ of unilateral ISK is caused by HSV. ${ }^{121}$ Other viruses causing ISK are VZV, EBV, mumpsvirus, rubellavirus, measlesvirus and influenzavirus. Tuberculosis, syphilis acanthamoebiasis and onchocerciasis are other infections associated with ISK. The complete differential diagnosis of stromal keratitis is extensive and beyond the scope of this review. In severe necrotizing disease, the clinical picture can be suggestive of bacterial keratitis, with ulceration, dense neutrophil infiltration and necrosis. Differential diagnosis of unilateral corneal edema with a normal endothelium in the opposite eye should bring up angle closure glaucoma and iridocorneal endothelial syndrome. When KPs are the only presenting sign other causes of anterior uveitis are possible.

Additionally, HSV has been implicated in other diseases of the anterior segment (Fig. 4 and table I). HSV DNA has been detected in the iridocorneal endothelial syndrome, ${ }^{\mathrm{I} 22, \mathrm{I} 23}$ in the aqueous humor during a period of intra-ocular pressure elevation in Posner-Schlossman syndrome ${ }^{124}$ and in idiopathic endotheliopathy. ${ }^{125,126}$

\section{Corneal HSV infections: pathogenesis and implications for therapy}

INFECTIOUS EPITHELIAL KERATITIS IEK results from viral replication in corneal epithelium and destruction of corneal epithelial cells: cytopathic effect of the virus. The duration of viral replication in the cornea depends on viral factors, including viral load, virus strain ${ }^{127}$ and host factors like immune status. 
The immune response in IEK consists of HSV-specific IgG and (s)IgA present in the tear film and corneal stroma, antibody-dependent cell-mediated cytotoxicity and HLA class I and class II restricted immune responses. ${ }^{\text {I28 }}$ In addition to the specific immune reaction, IFN$\alpha / \beta$ production by the infected epithelial cells limits the spread of the virus and allows resolution of the lesion. These dendritic lesions heal without scar formation, when the epithelium is the sole tissue affected. As the disease process continues, the infection can extend through the basement membrane, ${ }^{116}$ into keratocytes in the superficial corneal stroma underlying the site of the lesion resulting in HSK. ${ }^{\text {229, I30 }}$

In IEK topical application of antivirals accelerates the elimination of replicating virus from the cornea. ${ }^{\mathrm{II}}$ In this phase of the disease the immune response is directed at limiting the spread of the virus. Interference with this immune response, for instance by corticosteroids, may favor the spread of the virus into the stroma. ${ }^{132}$

NEUROTROPHIC KERATOPATHY HSV-induced neurotrophic lesions are neither infectious nor immunologic in origin. Neurotrophic keratopathy is a multifactorial disease. Impaired corneal innervation in combination with decreased tear secretion produces non-healing epithelial defects. Basement membrane damage and stromal inflammation interferes with normal epithelial wound healing.

The resulting damage should determine the therapeutic approach. Artificial tears in dry eye syndromes, protection of a vulnerable basement membrane by bandage contact lens, or low strength steroids in chronic stromal inflammation. The keratopathy may be exacerbated by the chronic use of topical medications, especially antiviral treatment and toxic antibiotics.

HERPETIC STROMAL KERATITIS The permanent loss of vision associated with HSV-I corneal infection is due to an inflammatory response in the corneal stroma. The immune response following an HSV corneal infection resembles that observed following HSV infection at nonocular sites. While the immune response elicited by the infecting virus is essential for limiting viral spread, it can have detrimental effects on the function of the cornea.

Studies on HSK have greatly benefited from the availability of several experimental animal models of the disease. Following inoculation of HSV-I on a scarified mouse cornea, the animal develops a delayed onset of corneal inflammation, a non-necrotizing form of HSK, that resembles many of the characteristics of recurrent ISK in humans. ${ }^{133,134}$ The only human specimens of active inflammation are those from necrotizing stromal keratitis. In immune stromal disease transplantation is preferably performed after inflammation has subsided.

Key events in the development of HSK involve the interaction between cornea infiltrating inflammatory cells and resident corneal cells. This interaction, in which macrophages producing IL-I and TNF$\alpha$, and IFN- $\gamma$ producing ThI cells play a pivotal role, results in the local secretion of immune-modulatory factors including various chemokines. 
HSK in the mouse is characterized by a bi-phasic cellular infiltrate of mainly neutrophils into the stromal layer. The first wave of neutrophils invading the cornea is only transient and is involved in viral clearance, ${ }^{135,136}$ whereas the second wave of neutrophils infiltration coincides with clinical manifestations of the disease. These neutrophils produce proteolytic enzymes, resulting in surrounding cell lysis and are probably responsible for most of the tissue damage. ${ }^{130}$ An essential factor for the development of HSK is the involvement of cornea infiltrating $\mathrm{CD}_{4}^{+}$ cells with a ThI phenotype. ${ }^{\mathrm{I} 7}$ These cells orchestrate the extravasation and activation of infiltrating neutrophils during the clinical phase of the disease. ${ }^{138,139, I 40, I 41,142}$ Neutrophils are known to secrete several other chemokines with possible antiviral function like IFN- $\alpha$, and TNF- $\alpha$ and nitric oxide. ${ }^{143}$ Production of Th2 cytokines, such as IL-IO and IL-4, detected in mouse corneas during the resolution phase, has been shown to inhibit HSK. ${ }^{\mathrm{I} 4}$

The ThI-derived cytokine IL-I7 has been shown to play an important role in several inflammatory diseases characterized by massive infiltration of neutrophils into inflamed tissue. ${ }^{145}$ Recently, expression of IL-I7 has been detected in corneas of NSK patients and activated intra-corneal $\mathrm{T}$ cell lines recovered from both ISK and NSK patients. Furthermore, human corneal fibroblasts (HCF) constitutively express the IL-I7 receptor. IL-I7 exhibited a strong synergistic effect with TNF- $\alpha$ on the induction of IL- 6 and IL- 8 secretion by HCF. Secreted IL-8 has a strong chemotactic effect on neutrophils. Additionally, ILI7 enhanced TNF- $\alpha$ and IFN- $\gamma$-induced secretion of macrophage inflammatory protein $\mathrm{I} \alpha$ and $3 \alpha$, while inhibiting the induced secretion of RANTES. These data strongly suggest that IL-I7 may play an important role in the induction or perpetuation of the immunopatholgenic process in human HSK by modulating the secretion of proinflammatory and chemotactic factors by corneal resident fibroblasts. ${ }^{146}$

The antigen specificity of the corneal infiltrating $\mathrm{T}$ cells in HSK remains a mystery. There are several partially conflicting theories on the antigen specificity of these T cells involved in HSK as seen in experimental mouse models. Recent studies have provided evidence that HSK in the mouse represents an autoimmune response to corneal tissue. ${ }^{\text {I47,I } 148, \mathrm{I} 49}$ HSK could be induced by $\mathrm{CD}_{4}{ }^{+} \mathrm{T}$ cells directed to an epitope derived from the HSV capsid protein UL6, which cross-reacts with an epitope of an antigen uniquely expressed in the murine cornea, ${ }^{\mathrm{I}}{ }^{\mathrm{e}, \mathrm{I} 48, \mathrm{I} 49}$ so-called molecular mimicry. Another explanation for the presence and activation of intra-corneal $\mathrm{CD}_{4}^{+} \mathrm{T}$ cells, is that the $\mathrm{T}$ cell response results from exposure to cytokines in the infected cornea, referred to as 'bystander activation'. ${ }^{150,151}$

Only very few studies have addressed the antigen-specificity of cornea infiltrating $\mathrm{T}$ cells in HSK patients. In contrast to the experimental HSK model, replicating virus and viral antigens ${ }^{152,153,154}$ have been demonstrated in the corneas, during the active as well as the inactive phase of stromal keratitis in humans. HSV-specific T cells can be detected in corneas of patients with both active and quiescent HSK, in patients treated with steroids and also in HSV DNA-negative corneas. These studies demonstrated that virus-specific $\mathrm{T}$ cells can reside in the cornea for longer periods of time. ${ }^{55,156,157}$ In parallel to studies in the 
experimental HSK mouse model the role of auto-immunity in human HSK was analyzed. In none of the T cell lines (TCLs) generated from corneas of HSK patients, reactivity to UL6 or a soluble protein extract of human corneas could be demonstrated. These data suggest that the T cell response in HSK patients is directed to the initiating virus and not to a human corneal autoantigen or HSV UL6. ${ }^{156}$

Intra-corneal TCL obtained from HSK patients contain high numbers of $\mathrm{HSV}$-specific $\mathrm{T}$ cells. ${ }^{15^{8}}$ Both $\mathrm{CD}_{4}^{+}$and $\mathrm{CD} 8^{+} \mathrm{T}$ cells are potentially involved in the intra-corneal HSV-specific T cell response. These data oppose results from studies performed in the experimental HSK mouse model in which corneal infiltrating $\mathrm{T}$ cells are predominantly of the $\mathrm{CD}_{4}^{+}$subset. Furthermore, the majority of the human intra-corneal TCL showed a restricted usage of $\mathrm{T}$ cell receptor $\mathrm{V} \beta$ domains. ${ }^{158}$

Antiviral treatment in ISK is both directed at the presumed presence of the virus and at prevention of severe reactivation of infection during steroid therapy. Topical antivirals should be used in a therapeutic dose. It has not been established that oral antiviral therapy is effective in acute stromal disease. However, visual acuity improved over 6 months in significantly more patients. ${ }^{159}$ The main indication for oral acyclovir in ISK is prevention of recurrent disease by a long-term low dose of acyclovir. ${ }^{160}$ Steroid therapy in stromal keratitis reduces the risk of persistent or progressive stromal keratitis by $68 \%$, and leads to a significant shorter time to resolution. ${ }^{161}$ Steroid dosage depends on the severity of disease. In corneal disease it is rarely necessary to use dosages exceeding dexamethasone 0.I \% six times a day. When edema and hyperemia are resolving tapering can be started slowly.

In case of NSK, both the viral replication and the severe immune response should be treated vigorously. Control of HSV replication should precede attempts to modulate the immune response. Both topical and systemic antiviral treatment should be used in high therapeutic doses, combined after two days with corticosteroid therapy. ${ }^{1{ }^{6} 2}$

CORNEAL ENDOTHELIITIS Endotheliitis probably results from lytic viral infection of the endothelium ${ }^{\mathrm{II} 8,163,164}$ with release of infectious virus into the aqueous. ${ }^{165,166,167}$ In addition to lytic infection of endothelial cells, viral antigens may be expressed on the surface of infected cells. Immunecompetent cells may attack the endothelium, leading to enhanced damage. This process is probably analogous to the cellular immune response in ISK. Histopathologic studies in patients with acute endotheliitis are missing. The immune response is deleterious to the eye because the endothelium has no regenerative capacity. Endothelial dysfunction leads to stromal and epithelial edema. Treatment is similar to immune stromal keratitis.

Summarizing discussion The finding, that HSV-I keratitis occurs after PKP in patients without a previous history of HSV keratitis, ${ }^{75}$ raises questions about the frequency and impact of this manifestation, about the mode of transmission in these patients, and about the numbers of transplant recipients at risk to develop this inflammatory disease. It is assumed that recurrent herpetic lesions are due to 
reactivation of the strain acquired during primary infection. However, HSV-I superinfection has been documented, but considered to be a relative rare event. ${ }^{168}$ Our data, however, demonstrate a high frequency of superinfection and suggest that PKP is a risk factor for corneal superinfection with HSV-I. ${ }^{24}$ Evidence is emerging that allograft rejection, ${ }^{169}$ primary graft failure, ${ }^{170}$ and endothelial cell loss of cultured eye bank corneas ${ }^{171,172}$ are associated with the presence of HSV-I DNA (Table 3). Future research should be directed at assessment of the risk of transmission of HSV-I through PKP the clinical impact of the infection on the patient's vision. These questions are reminiscent of the situation with other herpesviruses in transplantation. ${ }^{173,174}$

The immune response following an HSV corneal infection resembles that observed following HSV infection at non-ocular sites. While the immune response elicited by the infecting virus is essential for limiting viral spread, it can have detrimental effects on the function of the cornea. Currently, the mainstay of treatment in stromal herpetic keratitis consists of antiviral treatment in combination with steroids. ${ }^{74,161}$ Although the nature of the antigens recognized by the cornea infiltrating T-cells are still unknown, parts of the cascade of inflammatory responses are elucidated by studies in 'mice and man'. ${ }^{134,175,146,155,156,157,158}$ Development of new therapeutic strategies targeting specific HSKassociated cytokines/chemokines will be the challenge for the future to treat this sight-threatning disease more effectively.

\section{References}

I Roizman B. Herpesviridae. In: Fields BN et al editors. Fields virology, $3^{\text {rd }}$ ed. Philadelphia: Lippincott-Raven Publishers I996: $222 \mathrm{I}-2230$

2 Roizman B. The structure and isomerization of herpes simplex virus genomes. Cell I979; I6: 48I-494

3 Roizman B, Sears AE. Herpes simplex viruses and their replication. In: Fields BN et al editors. Fields virology, $3^{\text {rd }}$ ed. Philadelphia: Lippincott-Raven Publishers I996:223 I-2295

4 Whitley RJ. Herpes simplex viruses. In: Fields BN et al editors. Fields virology, $3^{\text {rd }}$ ed. Philadelphia: Lippincott-Raven Publishers I996: 2297-2342

5 Koelle DM, Reymond SN, Chen H, Kwok WW, McClurkan C, Gyaltsong T, Petersdorf EW, Rotkis W, Talley AR, Harrison DA. Tegument-specific, virus-reactive $\mathrm{CD}_{4} \mathrm{~T}$ cells localize to the cornea in herpes simplex virus interstitial keratitis in humans. J Virol 2000;74: I0930-I0938

6 Kristensson K, Lycke E, Sjostrand J. Spread of herpes simplex virus in peripheral nerve. Acta Neuropath I97I; I 7:44-53

7 Cook ML, Stevens JG. Latent herpetic infections following experimental viremia J Gen Virol I976;3 I:75-8I

8 Roizman B, Sears A. Inquiring into mechanisms of herpes simplex virus latency. Annu Rev Microbiol I987; 4I:543-57I

9 Roizman B, Sears A. Herpes simplex viruses and their replication. In: Roizman B, Whitley RJ, Lopez C eds. The human herpesviruses New York; Raven I993: I I-68

Io Simmons A, Bowden R, Slobedman B. T Retention of herpes simplex virus DNA sequences in the nuclei of mouse rootpad keratinocytes af ter recovery from primary infection. J Gen Viro I I997;78:867-87 I

I I Pavan-Langston D, Rong BL, Dunkel EC. Extraneuronal herpetic 
latency: animal and human corneal studies. Acta Ophthalmol Suppl I989;I92:I35-4I

I2 Cantin EM, Chen J, McNeill JI, Willey DE, Openshaw H. Detection of herpes simplex virus DNA sequences in corneal transplant recipients by polymerase chain reaction assays. Curr Eye Res I99I;I0 suppl:I5-2 I

I3 Kaye SB, Lynas C, Patterson A, Risk JM, Mc Carthy K, Hart CA. Evidence for herpes simplex viral latency in the human cornea. Br J Ophthalmol I991;75:195-200

I4 Asbell PA, Centifanto-Fitzgerald YM, Chandler JW, Kaufman HE. Analysis of viral DNA in isolates from patients with recurrent herpetic keratitis. Invest Ophthalmol Vis Sci I984;25:95I-954

I5 Sakaoka H, Aomori T, Gouro T, Kumamoto Y. Demonstration of either endogenous recurrence or exogenous reinfection by restriction endonuclease cleavage analysis of herpes simplex virus from patients with recrudescent genital herpes. J Med Virol. I995;46:387-396

I6 Whitley RJ, Lakeman AD, Nahmias A, Roizman B. DNA restrictionenzyme analysis of herpes simplex virus isolates obtained from patients with encephalitis. New Engl J Med I982;307:I060-I062

I7 Buchman TG, Roizman B, Nahmias AJ. Demonstration of exogenous reinfection with herpes simplex virus type-2 by restriction endonuclease fingerprinting of viral DNA. J Infect Dis I979;I40:295-304

I 8 Heller M, Dix RD, Baringer JR, Schachter J Conte JE Jr. Herpetic proctitis and meningitis: recovery of two strains of herpes simplex type I from cerebrospinal fluid. J Infect Dis I982; I46:584-588

I9 Lewis ME, Leung WC, Jeffrey VM, Warren KG. Detection of multiple strains of latent herpes simplex virus type I within individual human hosts. J Virol. I984;52: 300-305

20 Lakeman AD, Nahmias AJ, Whitley RJ. Analysis of DNA from recurrent genital herpes simplex virus isolates by restriction endonuclease digestion. J Sex Transm Dis I986; I3:6I-66

2I Schmidt OW, Fife KH, Corey L. Reinfection is an uncommon occurrence in patients with symptomatic recurrent genital herpes J Infect Dis I984;I49: 645-646

22 Lonsdale DM, Moira Brown S, Subak-Sharpe JH, Warren KG, Koprowsky H. The polypeptide and DNA restriction enzyme profiles of spontaneous isolates of herpes simplex virus type I infection from explants of human trigeminal, superior cervical and vagus ganglia. J Gen Virol I979;43:I5I-I7I

23 Maertzdorf J, Remeijer L, van der Lelij A, Buitenwerf J, Niesters HGM, Osterhaus ADME, Verjans GMGM. Amplification of reiterated sequences of herpes simplex virus type I (HSV-I) genome to discriminate between clinical HSV-I isolates. J Clin Microbiol I999;37: 35I8-3523

24 Remeijer L, Maertzdorf J, Buitenwerf J, Osterhaus ADME, Verjans GMGM. Corneal herpes simplex virus type I superinfection in patients with recrudescent herpetic keratitis. Invest Ophthalmol Vis Sci 2002;43:358-363

25 Liesegang TJ, Melton LJd, Daly PJ, et al. Epidemiology of ocular herpes simplex. Incidence in Rochester, Minnesota, I950 through I982. Arch Ophthalmol I989;I07:I I 55-I I59

26 Ragozzino MW, Melton LJ, Kurland LT, et al. Population based study of herpes zoster and its sequelae. Medicine I982;6I:3 I0-3I6

27 Murakami S, Mizobuchi M, Nakashiro Y, Doi T, Hato N, Yanagihara N. Bells Palsy and herpes simplex virus: identification of viral DNA in endoneurial fluid and muscle. Ann Intern Med I 996; I 24:27-30

28 Ljungman P. Herpesvirus infections in immunocompromised patients: problems and therapeutic 
interventions. Ann Med I993;25: 329-333

29 Arvin AM. Varicella-Zoster virus. In: Fields BN et al editors. Fields virology, $3^{\text {rd }}$ ed. Philadelphia: Lippincott-Raven Publishers I996: 2547-2579

30 Liesegang T. Diagnosis and therapy of herpes zoster ophthalmicus. Ophthalmology I99I;98:I2 I6-I 229

3 I Harding S, Lopton J, Wells J. Natural history of herpes zoster ophthalmicus: predictors of postherpetic neuralgia and ocular involvement. Br J Ophthamol I987;7 I:353-358

32 Sandor E, Millman A, Croxson TS Mildvan D. Herpes zoster ophthalmicus in patients at risk for the acquired immune deficiency syndrome (AIDS), Am J Ophthalmol I986;IOI:I53-I55

33 Shayegani A, Odel JG, Kazim M, Hall LS, Bamford N, Schubert H. Varicella-Zoster virus retrobulbar neuritis in a patient with Human immunodeficiency virus. Am J Ophthalmol I996; I22:586-588

34 Forster DJ,Dugel PU, Frangieh GT, Liggett PE, Rao NA. Rapidly progressive outer retinal necrosis in the acquired immune deficiency syndrome Am J Ophthalmol I99I; I I 0:34I-348

35 Junker $\mathrm{K}$ et al. Reinfection with varicella-zoster virus in immunocompromised patients. Curr Probl Dermatol I989;I8:I52-I57

36 Rickinson AB, Kieff E. EpsteinBarr virus In: Fields BN et al editors. Fields virology, $3^{\text {rd }}$ ed. Philadelphia: Lippincott-Raven Publishers I996:2397-2438

37 Crawford DH. Biology and disease associations of Epstein-Barr virus. Philos Trans R Soc Lond B Biol Sci 200I;356( I408)46I-473

38 Matoba A. Epstein-Barr virus diseases. In: Pepose JS, Holland GN, Wilhelmus KR, editors. Ocular infection and immunity. St Louis: Mosby-Year Book Inc I996:958-969

39 Tanner O. Ocular manifestations of infectious mononucleosis. Arch Ophthalmol I954;5I:229-24I
40 Daibata M, Komatsu T, Taguchi H. Human herpesviruses in primary ocular lymphoma. Leuk Lymphoma 2000;37:36I-365

4I Holland G, Tufail A, Jordan MC. Cytomegalovirus diseases. In: Pepose JS, Holland GN, Wilhelmus $\mathrm{KR}$, editors. Ocular infection and immunity. St Louis: Mosby-Year Book Inc I996: I089-I I 29

42 Jacobson MA, Mills J. Serious cytomegalovirus disease in the acquired immunodeficiency syndrome (AIDS): clinical findings, diagnosis and treatment, Ann Intern Med I988; I08: 585-594

43 Levy JA. Three new human herpesviruses (HHV6, 7, and 8) Lancet I997;349:558-563

44 Dockrell DH, Paya CV. Human herpesvirus- 6 and -7 in transplantation Rev Med Virol 200 I; I I:23-36

45 Brooks LA, Wilson AJ, Crook T. Kaposi's sarcoma associated herpesvirus (KSHV)/ human herpes virus 8 (HHV8) - a new human tumour virus. J Pathol I997; I82: 262-265

46 Chan C-C, Shen DF, Whitcup SM, Nussenblatt RB, Lehoang P, et al. Detection of Human herpesvirus- 8 and Epstein-Barr virus DNA in primary intraocular lymphomas. Blood I999;93:2749-275 I

47 Straus SE. Herpes simplex virus and its relatives. In: Schaechter M et al editors. Mechanisms of Microbial Disease, $3^{\text {rd }}$ ed. Publisher 380-390

48 Umene K, Sakaoke H. Evolution of herpes simplex virus type I under herpesvirus evolutionary processes. Arch Virol I999; I44:637-656

49 Nahmias AJ, Lee FK, Beckman-Nahmias S. Seroepidemiological and - sociological patterns of herpes simplex virus infection in the world. Scand J Infect Dis I990;69:S I9-S36

50 Corey L. The current trend in genital herpes. Progress in prevention. Sex Transm Dis I994;2 I:S38-S44 
5I Schillinger JA, McQuillan GM, Nahmias AJ, Lee FK, Johnson RE, St Louis ME. National prevalence of herpesvirus type I infection. Abstract presented at Interscience Conference on Antimicrobial Agents and Chemotherapy, San Diego, California September 24-27, I998

52 Wutzler P, Doerr HW, Farber I,

Eichhorn U, Helbig B, Sauerbrei A, Brandstadt A, Rabenau HF. Seroprevalence of Herpes Simplex Virus Type I and Type 2 in Selected German Populations-Relevance for the incidence of Genital Herpes. J.

Med. Virol 2000;6r:20I-207

53 Whitley RJ, Kimberlin DW, Roizman B. Herpes simplex viruses. Clin Infect Dis I998;26:54I-553

54 Roest RW, van der Meijden WI, van Dijk G, Groen J, Mulder PGH, Verjans GM, Osterhaus AD. Prevalence and association between herpes simplex virus types I and 2-specific antibodies in attendees at a sexually transmitted disease clinic. Int J Epidemiology 200 I;30: 580-588

55 Fleming DT, McQuillan GM, Johnson RE, Nahmias AJ, Aral SO, Lee FK, St Louis ME. Herpes simplex virus type 2 in the United States, I976-I994. N Eng J Med I997;337: I I05-I I I I

56 Kinghorn GR. Genital herpes: natural history and treatment of acute episodes. J Med Virol I993; Suppl (I):33-38

57 Dummer JS, Armstrong J, Somers J, et al. Transmission of infection with herpes simplex virus by renal transplantation. J Infect Dis I987; I 55:202-206

58 Goodman JL. Possible transmission of herpes simplex virus by organ transplantation. Transplantation I989;47:609-6I3

59 Data from the Dutch National Register for Corneal Transplantation under the auspices of the NOG, Cornea-werkgroep: Kok-van Alphen I995-200I

60 Salisbury JD, Berkowitz RA, Gebhardt BM, Kaufman HE.
Herpesvirus infection of cornea allografts. Ophthalmic Surg I984; I5: 406-408

6I Beyer CF, Byrd TI, Hill JM, Kaufman HE. Herpes simplex virus and persistent epithelial defects after penetrating keratoplasty. Am J Ophthalmol I990;I09:95-96

62 Mannis MJ, Plotnik RD, Schwab IR, Newton RD. Herpes simplex dendritic keratitis after keratoplasty.Am J Ophthalmol I99I;11l:480-484

63 Beyer CF, Hill JM, Byrd TJ, Kaufman HE. Herpes simplex dendritic keratitis after keratoplasty letter. Am J Ophthalmol i99i; I 2: 355-356

64 Liesegang TJ Melton Ljd, Daly PJ, et al. Epidemiology of ocular herpes simplex. Incidence in Rochester, Minn, I950 through I982. Arch Ophthalmol I989;I07: I I55-I I59

65 Dekkers NWHM, Treskes M. Measles keratitis. Ophthalmol Clin North America I994;7:567-576

66 Pavan Langston D. Viral diseases of the cornea and the external eye. In: Jakobiec F, Albert D, eds. Principle and practise of ophthalmology. Philadelphia: Saunders I994: I I7-I6I

67 Liesegang TJ, Melton LJd, Daly P, et al. Epidemiology of ocular herpes simplex: incidence in Rochester, Minnesota, I950 through I982. Arch Ophthalmol I989;I07: I I55-I I 59

68 Darougar S, Wishart MS, Vishwalingham ND. Epidemiological and clinical features of primary herpes simplex virus ocular infection. $\mathrm{Br} \mathrm{J}$ ophthalmol I985;69:2-6

69 Carrol J, Martola EC, Laibson PR, et al. The recurrence of herpetic keratitis following IDU therapy. Am J Ophthalmol I967;63:I03-I07

70 Herpetic eye disease study group. Predictors of recurrent herpes simplex virus keratitis. Cornea 200 I;20:I23-I28

7I Data from the Dutch National Register for Corneal 
Transplantation under the auspices of the NOG werkgroep Kok-van Alphen I995-200 I

72 Sterk CC, Jager MJ, Swart-vd Berg. Recurrent herpetic keratitis in penetrating keratoplasty. Doc Ophthalmol I995;90:29-33

73 Barney NP, Foster CS. A prospective randomised trial of oral acyclovir after penetrating keratoplasty for herpes simplex keratitis. Cornea I994;I3:232-236

74 The Herpetic Eye Disease Study Group: Acyclovir for the prevention of recurrent herpes simplex virus eye disease. N Engl J Med I998;339: 300-306

75 Remeijer L, Doornenbal P, Geerards AJ, Rijneveld WA, Beekhuis WH. Newly acquired herpes simplex virus keratitis after penetrating keratoplasty. Ophthalmology I997;I04:648-652

76 Liesegang TJ. A community study of ocular herpes simplex. Curr Eye Res I99I;Io(suppl): I I I-I I5

77 O'Day D. Diseases potentially transmitted through corneal transplantation. Ophthalmol I989;96: I I33-I I37

78 Remeijer L, Maertzdorf J, Doornenbal P, Verjans GMGM, Osterhaus ADME. Herpes simplex virus I transmission through corneal transplantation. The Lancet 200I;357:442

79 Abbas AK, Lichtman AH, Pober JS. Immunity to viruses: In Cellular and molecular immunology, $3^{\text {rd }}$ ed. Philadelphia: WB Saunders, I997:ch I6:35 I-353

$80 \mathrm{Wu}$ L, Morahan PS. Macrophages and other non specific defenses: role in modulating resistance against herpes simplex virus. In: Herpes simplex virus: pathogenesis, immunobiology and control. Rouse BT ed. Berlin: Springer-Verlag I992; 89-I Io

8I Ching C, Lopez C. Natural killing of herpes simplex virus type 1-infected target cells: normal human responses and influence of antiviral antibody. Infection and immunity I979;26:49-56
82 Birron CA, Nguyen KB, Pien GC, Cousens LP, Salazar TP. Natural killer cells in antiviral defense: function and regulation by innate cytokines. Ann Rev Immunol I999;I 7:I89-220

83 Ploegh HL. Viral strategies of immune evasion. Science I998;280: 248-253

84 Vilcek J, Sen GC. Interferons and other cytokines. In: Fundamental Virology, ed Fields BN, Knipe DM, Howley PM. In: Fields BN et al editors. Fundamental virology, Philadelphia: Lippincott-Raven Publishers I996:34I-365

85 Glorioso J, Schroder CH, Kumel G, Szczesiul M, Levine M. Immunogenicity of herpes simplex virus glycoproteins $\mathrm{gC}$ and $\mathrm{gB}$ and their role in protective immunity $\mathrm{J}$ Virol I984;50:805-8I2

86 Para MF, Parish ML, Noble AG, Spear PG. Potent neutralizing activity associated with glycoprotein D specificity among monoclonal antibodies selected for binding to herpes simplex virions. J Virol I $985 ; 55: 483-488$

$87 \mathrm{Kohl} \mathrm{S}$. The role of antibody in herpes simplex virus infections in humans. Current topics in microbiology and immunology I992; I79:75-88

88 McKendall RR, Klassen T, Baringer JR. Host defenses in herpes simplex infections of the nervous system: effect of antibody on disease and viral spread. Infect Immun I979;23: 305-3 I I

89 Schmid DS, Rouse BT. The role of $\mathrm{T}$ cell immunity in control of herpes simplex virus. Current Topics Microbiol. Immunol I992; I79: $57-74$

90 Wiertz EJHJ, Mukherjee S, Ploegh HL. Viruses use stealth technology to escape from the host immune system. Mol Med Today I997;3: I I6-I 23

9I Barcy S, Lawrence C. Herpes simplex inhibits the capacity of lymphoblastoid B cells to stimulate CD4+ T cells. J Immunol 200 I; 66 : 6242-6249 
92 Jerome KR, Fox R, Chen Z, Sarkar $\mathrm{P}$, Corey L. Inhibition of apoptosis by primary isolates of herpes simplex virus. Arch Virol 200I;I46: 22I9-2225

93 Wiertsz E, Hill A, Tortorella D, Ploegh H. Cytomegalovirus use multiple mechanisms to elude the host immune system. Immunology letters I997;57:2 I3-2 I6

94 McNearny TA, Odell C, Holers VM, Spear PG, Atkinson JP. Herpes simplex virus glycoproteins $\mathrm{gC}$ - $\mathrm{I}$ and $\mathrm{gC}-2$ bind to the $3^{\text {rd }}$ component of complement and provide protection against complement mediated neutralization of viral infectivity. J Exp Med I987; I66: I525-I535

95 Dubin G, Fishman NO, Eisengerg RJ, Cohen GH, Friedman HM. The role of herpes simplex virus glycoproteins in immune evasion. In: Rouse BT ed. Herpes simplex virus: Pathogenesis, Immunobiology and Control Berlin: Springer-Verlag I 992: I I I-I 2 I

96 Doymaz MZ, Rouse BT. Immunopathology of herpes simplex virus infections. In: Rouse BT ed. Herpes simplex virus: Pathogenesis, Immunobiology and Control. Berlin: Springer-Verlag I992:57-74

97 Whitton L, Fujinami RS. Viruses as triggers of autoimmunity: facts and fantasies. Current opinion in microbiology I999;2:392-397

98 Arffa RC. Anatomy of the cornea. In: Arffa RC ed. Grayson's Diseases of the cornea. St Louis, Mosby-Year Book I99I;ch I:I-24

99 Schimmelpfennig B. Nerve structures in human central corneal epithelium. Graefes Arch Clin Exp Ophthalmol I982;2 I8:I4-20

Ioo Muller LJ, Pels L, Vrensen GJ. Ultrastructural organization of human corneal nerves. Invest Ophthalmol Vis Sci I996;37:476-487 Io I Müller LJ, Vrensen GFJM, Pels L, Nunes Cardozo B, Willekens B. Architecture of human corneal nerves. Invest Ophthalmol Vis Sci I997;38:985-994
IO2 Niederkorn JY. Immune privilege and immune regulation in the eye. Adv Immunol I990;48:I9I-226

I03 Dana MR, Streilein JW. Loss and restoration of immune privilege in eyes with corneal neovascularization. Invest Ophthalmol Vis Sci 1996;37: 2485-2494

I04 Novak N, Siepmann K, Zierhut M, Bieber T. The good, the bad and the ugly- APC of the eye. Trends Immunol 2003;24:570-574

I05 Dana MR, Dai R, Zhu S, Yamada J, Streilein JW. Interleukin-I receptor antagonist suppresses Langerhans cell activity and promotes ocular immune privilege. Invest Ophthalmol Vis Sci 1998;39:70-77

Io6 Griffith TS, Brunner T, Fletcher SM, Green DR, Ferguson TA. Fas Ligand-induced apoptosis as a mechanism of immune privilege. Science I995;270:II89-II92

I07 Taylor AW, Alard P, Yee DG, Streilein JW. Aqueous humor induces transforming growth factorbeta (TGF- $\beta$ )-producing regulatory T cells. Curr Eye Res I997; I6: 900-908

Io8 Okamoto S, Streilein JW. Role of inflammatory cytokines in induction of anterior chamber associated immune deviation. Ocul Immunol Inflamm I998;6:I-I I

Io9 Holland EJ, Schwartz GS. Classification of herpes simplex virus keratitis. Cornea I999; 8 : I44-I54

I Io Liesegang TJ. Classification of herpes simplex virus keratitis and anterior uveitis. Cornea I999; 8 : I 27-I 43

I I Tabery HM. Epithelial changes in early primary herpes simplex keratitis. Photomicrographic observations in a case of human infection. Acta Ophthalmol Scand 2000;78:706-709

I 2 Pavan-Langston D. Herpetic infections. In: Smolin G, Thoft RA eds. The cornea Boston: Little, Brown I994;240-26I

I 3 Spencer WH, Hayes TL. Scanning and transmission electron 
microscopic observations of the topographic anatomy of dendritic lesions in the rabbit cornea. Invest Ophthalmol Vis Sci I970;9: I83-I95

I I4 Harnisch JP, Hoffmann F. Scanning electron microscopic investigations on the development of the dendritic lesion in the corneal epithelium. In: Herpetic eye disease. Sundmacher, $\mathrm{R}$ ed. JF Bergmann Verlag, München I98I;I75-I78

I 5 Lohmann A, Müller LJ, Pels E, Mulder PGH, Remeijer L. A Hypothesis for the Dendritic Pattern of Epithelial Herpes Simplex Virus Keratitis. Poster at the ARVO Annual Meeting, Fort Lauderdale, I999 (\#290I)

I 6 Holbach LM, Font RL, Wilhelmus KR. Recurrent herpes simplex keratitis with concurrent epithelial and stromal involvement. Arch Ophthalmol I99I;I09:692-695

I 7 Thygeson P. Marginal herpes simplex keratitis simulating catarrhal ulcer. Invest Ophthalmol Vis Sci I97I;I0:I006

I 8 Vannas A, Ahonen R, Makitie J. Corneal endothelium in herpetic keratouveitis Arch Ophthalmol I983;I0I:9I3-9I5

I I9 Olsen TW, Hardten DR, Meiusi RS, Holland EJ. Linear endotheliitis. Am J Ophthalmol I994; I I7:468-474

I20 Wilson SE, Kaufman HE. Graft failure after penetrating keratoplasty. Surv of Ophthalmol I990;34:325-356

I2 I Schwartz GS, Harrison AR, Holland EJ. Etiology of immune stromal (interstitial) keratitis. Cornea I998; I 7:278-28I

I22 Groh MI, Seitz B, Schumacher S, Naumann GO. Detection of herpes simplex virus in aqueous humor in iridocorneal endothelial (ICE) syndrome. Cornea. I999; I8:359-360

I23 Alvarado JA, Underwood JL, Green WR, Wu S, Murphy CG, Hwang DG, Moore TE, O'Dav D. Detection of herpes simplex viral DNA in the iridocorneal endothelial syndrome. Arch Ophthalmol I994;II2:I60I-I609
I24 Yamamoto S, Pavan-Langston D, Tada R, Yamamoto R, Kinoshita S, Nishida K, Shimomura Y, Tano Y. Possible role of herpes simplex virus in the origin of PosnerSchlossman syndrome. Am J Ophthalmol I995; I 19:796-79

I25 Dayan M, McGhee C, Anastas C. Idiopathic sectoral corneal endotheliitis. Aust NZ J Ophthalmol I996;24:357-359

I26 Scott DR, Pepose JS, Lee SF, Charles NC, Cykiert RC, Barraquer J, de la Cruz Z, Green WR. Congenital idiopathic corneal endotheliopathy. Arch Ophthalmol I989; I07: I I 86-I I92

I27 Wander AH, Centifanto-Fitzgerald YM, Kaufman HE. Strain specificity of clinical isolates of herpes simplex virus. Arch Ophthalmol I980;98: I458-I46I

I28 Missotten L. Immunology and herpetic keratitis. Eye I994;8:I2-2 I

I29 Wilson SE, Pedroza L, Beuerman R, Hill JM. Herpes simplex virus type-I infection of corneal epithelial cells induces apoptosis of the underlying keratocytes. Exp Eye Res I997;64:775-779

I30 Thomas J, Gangappa S, Kanangat S, Rouse BT. On the essential involvement of neutrophils in the immunopathologic disease: Herpetic stromal keratitis. J Immunol I997;I58:I383-I39I

I3 I Wilhelmus KR. The treatment of herpes simplex virus epithelial keratitis. Trans Am Ophthalmol Soc 2000;98:505-532

I32 Nasisse MP, Guy JS, Davidson MG, Sussman WA, Fairly NM.

Experimental ocular herpesvirus infection in the cat. Sites of virus replication, clinical features and effects of corticosteroid administration. Invest Ophthalmol Vis Sci I989;30:I758-I768

I33 Doymaz MZ, Rouse BT. Immunopathology of herpes simplex infections. Cur Top Microbiol Immunol I992; I79: I 2 I-I36

I34 Streilein JW, Dana MR, Ksander BR. Immunity causing blindness: 
five different paths to herpes stromal keratitis. Immunology Today I997; I 8:443-449

I35 Tumpey TM, Chen SH, Oakes JE, Lausch RN. Neutrophil-mediated suppression of virus replication after herpes simplex virus type I infection of the murine cornea. J Virol I996;70:898-904

I36 Thomas J, Kanangat S, Rouse BT. Herpes simplex virus replicationinduced expression of chemokines and pro-inflammatory cytokines in the eye: Implication in herpetic stromal keratitis. J. Interferon. Cytokine Res. I998;I8:68I-689

I37 Metcalf JF, Hamilton DS, Reichert RW. Herpetic keratitis in athymic (nude) mice. Infect Immun I979;26: I I64-I I 7 I

I38 Russel RG, Nasisse MP, Larsen HS, Rouse BT. Role of T-lymphocytes in the pathogenesis of herpetic stromal keratitis. Invest Ophthalmol Vis Sci I984;25:938-944

I39 Newel CK, Martin S, Sendele D, Mercadal CM, Rouse BT. Herpes simplex virus induced stromal keratitis: role of T-lymphocyte subsets in immunopathology. J Virol I989;63:769-775

I40 Hendricks RL, Tumpey TM. Contribution of virus and immune factors to herpes simplex type-I induced corneal pathology. Invest Ophthalmol Vis Sci I990;30: I929-I939

I4I Hendricks RL, Tumpey TM, Finnegan A. IFN-gamma and IL-2 are protective in the skin but pathologic in the corneas of HSV-Iinfected mice. J Immunol I992; I49: 3023-3028

I42 Niemialtowski MG, Rouse BT. Predominance of Th I cells in ocular tissue during herpetic stromal keratitis. J Immunol I992; I49:3023

I43 Cassatella MA. The production of cytokines by polymorphonuclear neutrophils. Immunol Today I995; I6:2 I-26

I44 Tumpey TM, Elner VM, Chen S-H, Oakes JE, Lausch RN. Interleukin-Io treatment can suppress stromal keratitis induced by herpes simplex type-I. J Immunol I992;I994:I53:2258-2265 I45 Moseley TA, Haudenschild DR, Rose L, Reddi AH. Interleukin-I7 family and IL-I7 receptors. Cytokine Growth Factor Rev. 2003; I4: I55-I74

I46 Maertzdorf J, Osterhaus AD, Verjans GM. IL-I7 expression in human herpetic stromal keratitis: modulatory effects on chemokine production by corneal fibroblasts. J Immunol 2002 Nov I5; I69(I0): 5897-5903

I47 Avery AC, Zhao ZS, Rodriguez A, Bikoff EK, Soheillan M, Foster CS, Cantor H. Resistance to herpes stromal keratitis conferred by an IgG2a-derived peptide. Nature I995;376:43 I-434

I48 Panoutsakopoulou V, Sanchirico ME, Huster KM, Jansson M, Granucci F, Shim DJ, Wucherpfennig KW, Cantor H. Analysis of the relationship between viral infection and autoimmune disease. Immunity. 200I Jul;I5(I):I37-I47

I49 Zhao Zs, Granucci F, Yeh L, Scaffer PA, Cantor H. Molecular mimicry by herpes simplex virus type-I: autoimmune disease after viral infection. Science I998;279: I344-I347

I50 Gangappa S, Babu JS, Thomas J, Daheshia M, Rouse BT. Virusinduced immunoinflammatory lesions in the absence of viral antigen recognition. J Immunol I998; I6r:4289-4300

I5I Gangappa S, Deshpande SP, Rouse BT. Bystander activation of $\mathrm{CD}_{4}^{+} \mathrm{T}$ cells accounts for herpetic ocular lesions. Invest Ophthalmol Vis Sci 2000;4I:453-459

I52 Easty DL, Shimeld C, Claoue CMP, Menage M. Herpes simplex virus isolation in chronic stromal keratitis: human and laboratory studies. Curr Eye Res I987;6:69-74

I53 Holbach LM, Font LR, Naumann GO. Herpes simplex stromal and endothelial keratitis. Granolomatous reactions at the 
level of Descemet's membrane, the stroma and Bowman's layer.

Ophthalmology 1990;97:722-728

I54 Kaye SB, Baker K, Bonshek R, Maseruka H, Grinfeld E, Tullo A, Easty DL, Hart CA. Human herpes viruses in the cornea. B J ophthalmol 2000:84:563-57 I

I55 Verjans GMGM, Remeijer L, van Binnendijk RS, Cornelissen JGC, Volker-Dieben HJ, Baarsma GS, Osterhaus ADME. Identification and characterization of herpes simplex virus-specific $\mathrm{CD}_{4}+\mathrm{T}$ cells in corneas of herpetic stromal keratitis patients. JID I998; I77: 484-488

I56 Verjans GMGM, Remeijer L, Mooy CM, Osterhaus ADME. Herpes simplex virus-specific $\mathrm{T}$ cells infiltrate the cornea of patients with herpetic stromal keratitis: no evidence for auto-reactive T cells. Invest Ophthalmol Vis Sci 2000;4I: 2607-26I 2

I57 Koelle DM, Reymond SN, Chen H, Kwok WM, McClurkan C, Gyaltsong T, Petersdorf EW, Rotkis W, Talley AR, Harrison DA. Tegument-specific, virus-reactive $\mathrm{CD}_{4} \mathrm{~T}$ cells localize to the cornea in herpes simplex virus interstitial keratitis in humans. J Virol 2000;74: I0930-I0938

I58 Maertzdorf J. Verjans GM, Remeijer L, van der Kooi, Osterhaus ADME. Restricted T cell receptor $\beta$-chain variable region protein use by cornea-derived CD4+ and CD8+ herpes simplex virus-specific $\mathrm{T}$ cells in patients with herpetic stromal keratitis. JID 2003; I87:550-558

I59 Herpetic Eye Disease Study Group. A controlled trial of oral acyclovir for herpes simplex stromal keratitis. Ophthalmol I994; I0I: I 87 I-I 882

I6o The Herpetic Eye Disease Study Group: Acyclovir for the prevention of recurrent herpes simplex virus eye disease. N Engl J Med I998;339: 300-306

I6I The Herpetic Eye Disease Study Group. A controlled trial of topical corticosteroids for herpes simplex stromal keratitis. Ophthalmol I994;IOI: I 883-896

I62 Lee SY, Laibson PR. Medical management of herpes simplex ocular infections. Int Ophthalmol Clin I996;36:85-97

I63 Holbach LM, Font LR, Naumann GO. Herpes simplex stromal and endothelial keratitis.

Granolomatous reactions at the level of Descemet's membrane, the stroma and Bowman's layer. Ophthalmology I990;97: 722-728

I64 Holbach LM, Asano N, Naumann GO. Infection of the corneal endothelium in herpes simplex keratitis. Am J Ophthalmol I998; I 26:592-594

I65 Sundmacher R, Neumann-Haefelin D. Herpes simplex virus-positive and negative keratouveitis. In: Silverstein AM, O'Connor GR eds. Immunology and Immunopathology of the eye. New york: Masson Publishing USA I979:225-229

I66 Vannas A, Ahonen R. Herpetic endothelial keratitis. A case report Acta Ophthalmol (Copenh) I98I; 59:296-30I

I67 Robin JB, Steigner JB, Kaufman HE. Progressive herpetic corneal endotheliitis. Am J Ophthalmol I985; I00:336-337

I68 Asbell PA, Centifanto-Fitzgerald YM, Chandler JW, Kaufman HE. Analysis of viral DNA in isolates from patients with recurrent herpetic keratitis. Invest Ophthalmol Vis Sci I984;25: 95I-954

I69 van Gelderen BE, Van der Lelij A, Treffers WF, van der Gaag R. Detection of herpes simplex virus type I, 2 and varicella zoster virus DNA in recipient corneal buttons.Br J Ophthalmol 2000;84: I238-I 243

I70 Cockerham GC, Bijwaard K, Sheng ZM, Hidayat AA, Font RL, McLean IW. Primary graft failure: a clinicopathologic and molecular analysis. Ophthalmology 2000;107: 2083-90; discussion 2090-209I 
I7I Tullo AB, Marcyniuk B, Bonshek R, et al. Herpes virus in a corneal donor. Eye I990;4: 766-767

I72 Sengler U, Reinhard T, Adams O, Krempe C, Sundmacher R. Herpes simplex virus infection in the media of donor corneas during organ culture: frequency and consequences. Eye 200I; 5 : 644-647

I73 Lopez-Rocafort L, Brennan DC. Current review of cytomegalovirus in renal transplantation. Minerva Urol Nefrol 200I;53(3):I45-I58

I74 Boubenider S, Hiesse C, Goupy C, Kriaa F, Marchand S, Charpentier B. Incidence and consequences of post-transplantation lymphoproliferative disorders. J Nephrol I997;I0(3):I36-I45

I75 Hendricks RL. An immunologist's view of herpes simplex keratitis: Thygeson lecture I996. Cornea I997; I6:503-506

I76 Herpetic eye disease study group. Acyclovir for the prevetion of recurrent herpes simplex virus eye diseases. N Engl J Med I998;339: 300-306

I77 Liesegang TJ. Epidemiology of ocular herpes simplex. Natural history in Rochester, Minnesota I950 through I982. Arch Ophthalmol I989;I07:I I60-I I65

I78 Williams HP, Falcon MG, Jones BR. Corticosteroids in the management of herpetic eye disease. Trans Ophthalmol Soc UK 1977;97:3 I-34

I79 Baarsma GS. Data from the Dutch Uveitis group, personal communication dd. I7-02-2002

I80 Remeijer L. Clinical impact of newly acquired HSV-I keratitis after penetrating keratoplasty. Unpublished observation

I8I Wilhelmus KR, Stulting RD, Sugar J, Khan MM. Primary corneal graft failure. A national reporting system. Medical Advisory Board of the Eye Bank Association of America. Arch Ophthalmol I995; I I3:I497-I502

I82 Cockerham GC, Krafft AE, McLean IW. Herpes simplex virus in primary graft failure. Arch Ophthalmol I997; I 5:586-589 
